\title{
THE 1984 CHILLAGOE SURVEYS
}

\author{
BRUNO DAVID \\ Department of Anthropology \& Sociology, The University of Queensland \\ Queensland 4072
}

\begin{abstract}
The results of a systematic archaeological survey at Chillagoe (north Queensland) are presented. Observations are made concerning site location and the effects of ground visibility on site patterning. This paper concludes with a working model of site patterning at Chillagoe during recent prehistory.
\end{abstract}

\section{Introduction}

This paper reports on systematic site surveys undertaken at Chillagoe in mid-1984. The surveys were undertaken as part of a broader project aimed at obtaining information on settlement-subsistence systems in the region (David 1987). In particular, they aimed at recovering information about archaeological site characteristics, including, environmental context, in order that a site locational model for the later stages of Aboriginal prehistory in the Chillagoe region might be generated. This paper presents the data gathered during this research and concludes with a site locational model.

\section{The Chillagoe Region}

Chillagoe is located $c .140 \mathrm{~km}$ west of Cairns, north Queensland (Fig. 1). It lies along the western slopes of the Great Dividing Range, immediately northwest of the Atherton Tablelands. Chillagoe is renowned for its limestone karst towers, many of which possess deep caves of palaeontological importance. The towers of the limestone belt stretch from near the Walsh River in the north to Almaden in the south. The maximum width of the limestone belt is $11 \mathrm{~km}$.

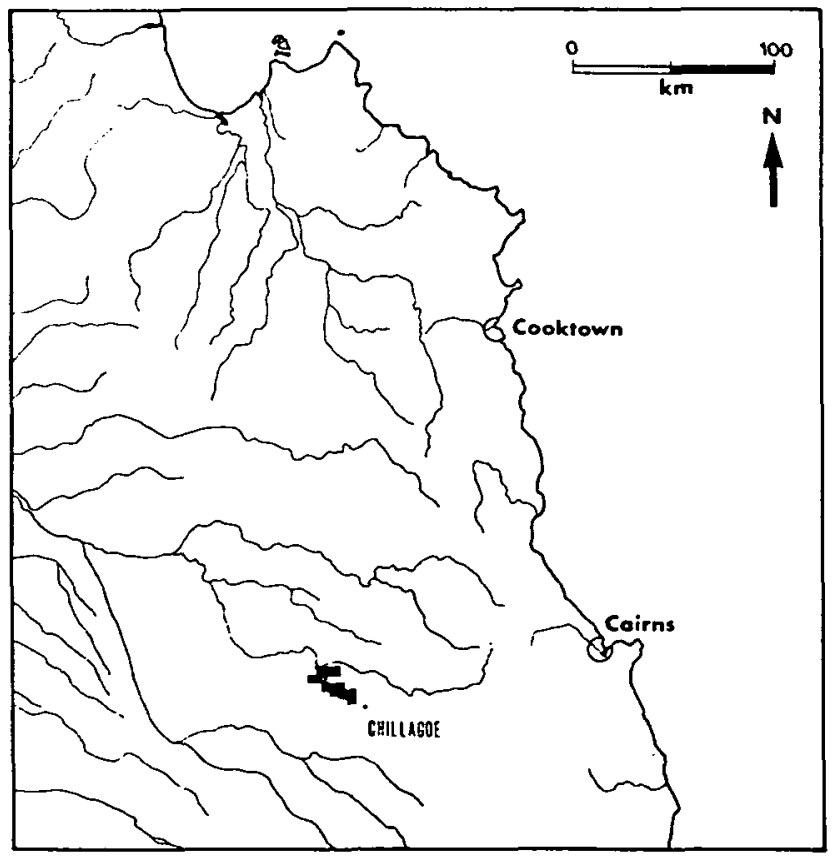

Figure 1. Map of north Queensland, showing locations of Chillagoe and the study region.
Rainfall around Chillagoe is greatly influenced by the interaction of seasonal monsoons and southeasterly Trade Winds. As a result, the region is characterised by a marked wet season (November-April), followed by a period of very little rain (May-October). There is an annual mean of 65 days and $800-900 \mathrm{~mm}$ of rainfall at Chillagoe, with the wet season months of DecemberMarch receiving c. $90 \%$ of the annual rainfall between them (Fig. 2). This marked wet-dry season dichotomy is thus likely to be an important factor for settlementsubsistence practices in Chillagoe prehistory.

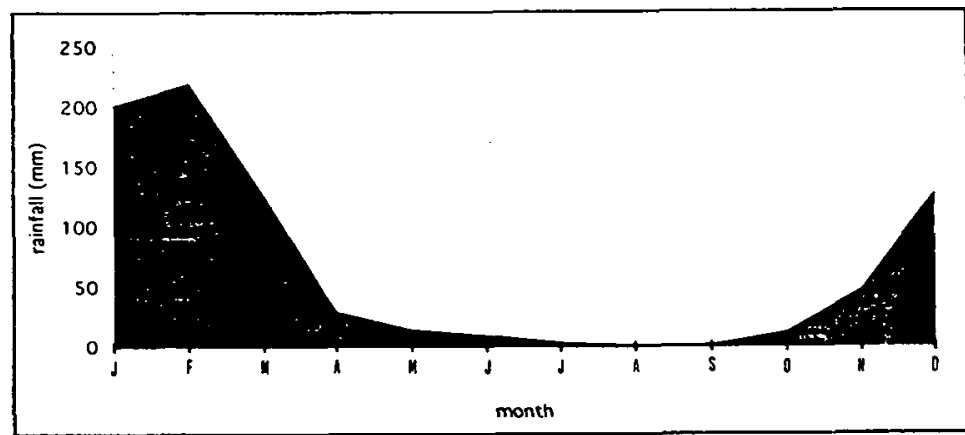

Figure 2. Mean annual rainfall, Chillagoe.

\section{The Survey Region}

An area measuring $20 \mathrm{~km}$ (north-south) $\times 17 \mathrm{~km}$ (eastwest) maximum dimensions was chosen for systematic archaeological surveys to the immediate north of the township of Chillagoe (Fig. 3). The survey region covers $145 \mathrm{~km}^{2}$, centring on co-ordinates $144^{\circ} 22^{\prime} \mathrm{E}$ and $17^{\circ} 3$ 'S. This region is bounded to the north by the Walsh River, to the south and west by the Sentinel Ranges, and to the east by Bungabilly Creek. The reasons for choosing this area was systematically to sample the northern parts of the Chillagoe limestone belt, thus offering a data base with which to compare and contrast archaeological results emanating from the southern parts of the limestone belt (Walkunder Arch Cave, Campbell [1982]).

At the time this survey was undertaken, the only archaeological results from the Chillagoe region came from excavations in an un-named (and as yet un-analysed) rockshelter by Wright (1971) and Walkunder Arch Cave (Birkett 1983, Campbell 1982, David 1983). Since then, our understanding of the prehistory of the region has increased through the works of Campbell (e.g. 1984), Mardaga-Campbell (1986), David (e.g. 1987, 1991, 1994) and others (e.g. Lamb 1993) (see Fig. 1). In spite of this, no systematic archaeological surveys have yet been 
published for the region, and no settlement-subsistence modelling has yet been attempted. This paper is an attempt to fill this gap.

For the purposes of this work, the study region was sub-divided into four land units, differentiated on the basis of: 1. topography; 2 . near-surface lithologies and edaphic conditions; 3 . drainage characteristics; and 4. vegetation. The four land units are: Plains, Hills, the Riverine Zone and Limestone Karst Towers (Table 1; Fig. 3).

Table 1. Land Units.

\begin{tabular}{|l|l|l|l|l|}
\hline & \multicolumn{1}{|c|}{ Topography } & \multicolumn{1}{c|}{ Lithology } & \multicolumn{1}{c|}{ Drainage } & \multicolumn{1}{c|}{ Vegetation } \\
\hline plains & flat plains & Quaternary alluvials & very poor & savanna woodland (dry sclerophyll \\
\hline hills & undulating slopes & $\begin{array}{l}\text { chert, greywacke, } \\
\text { quartzite, siltstone, } \\
\text { conglomerate, some } \\
\text { granite }\end{array}$ & good & $\begin{array}{l}\text { savanna woodland (dry } \\
\text { sclerophyll) }\end{array}$ \\
\hline riverine & flat lands & Quaternary alluvials & very poor & $\begin{array}{l}\text { vine thickets, dry \& wet } \\
\text { sclerophyll }\end{array}$ \\
\hline karst & $\begin{array}{l}\text { sloping pediments, } \\
\text { limestone karst } \\
\text { towers }\end{array}$ & limestone towers & very good & microphyll vine thickets \\
\hline
\end{tabular}

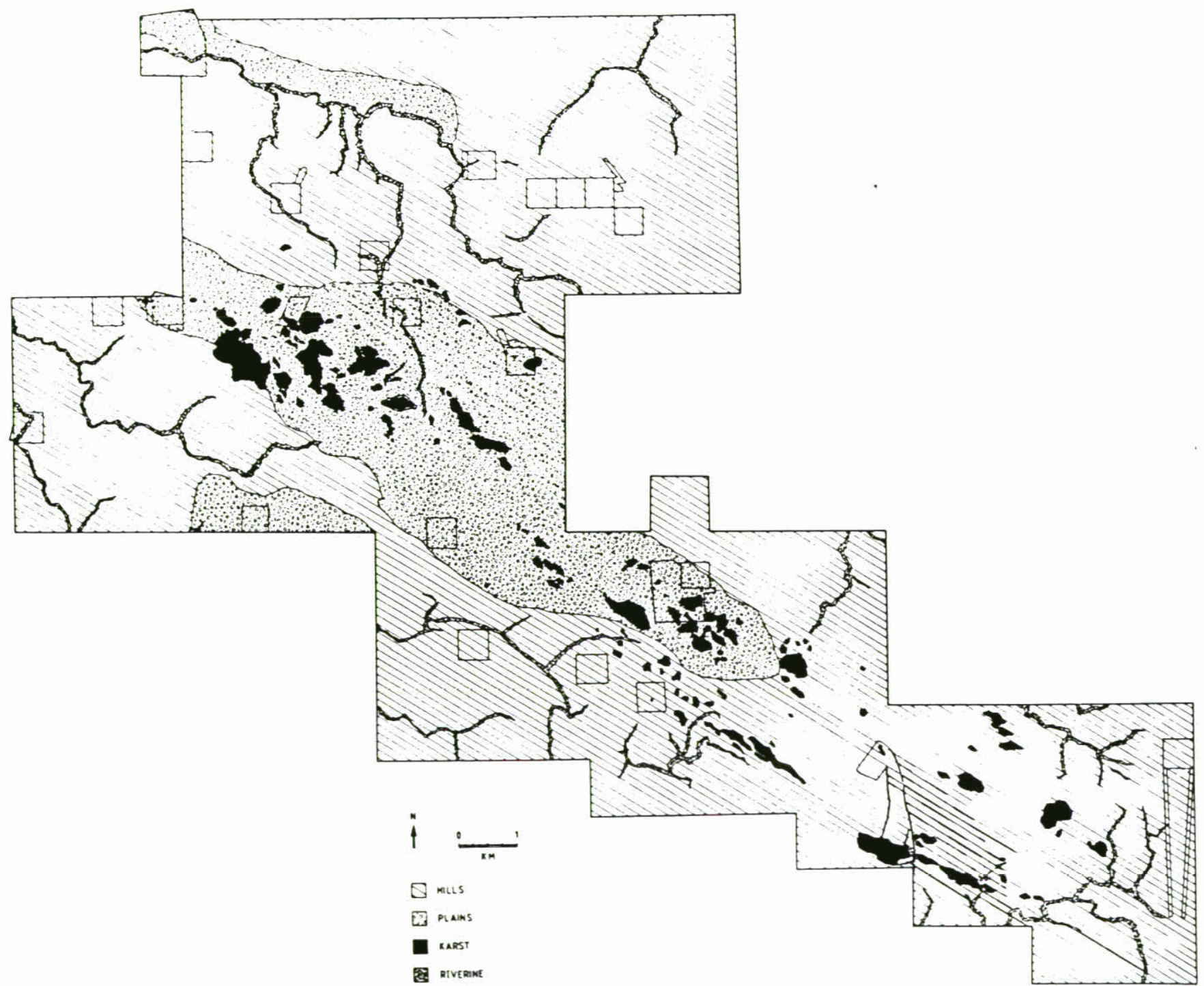

Figure 3. Survey region, showing the four land units and the surveyed areas. 


\section{The Plains}

The Plains cover $35 \mathrm{~km}^{2}$, or $24 \%$ of the study area. The predominant plant species are Eucalyptus leptophleba, E. cullenii, E. dichromophloia, Heteropogon contortus and Themeda australis. The Plains contain 17 edible plant taxa, including tubers, seeds and nuts, sweet flowers, shoots and fruits (Table 2). Surface sediments consist of
Quaternary alluvial deposits, with slope gradients of $<2^{\circ}$ resulting in poor drainage, especially during the wet season. Although the Plains were usually easily differentiated from other land units in the field and on aerial photographs, at times they graded into the surrounding Hills (Fig. 4).

Table 2. Edible plants growing on the Plains. $\sqrt{ }=$ present, $?=$ probably present.

\begin{tabular}{|c|c|c|c|c|c|c|c|c|c|c|c|c|}
\hline Plant Resource & Jan & Feb & Mar & Apr & May & June & July & Aug & Sep & Oct & Nov & Dec \\
\hline \multicolumn{13}{|l|}{ TUBERS } \\
\hline Acacia bidwillii & $\sqrt{ }$ & $\sqrt{ }$ & $\sqrt{ }$ & $\sqrt{ }$ & $\sqrt{ }$ & $\sqrt{ }$ & $\sqrt{ }$ & $\sqrt{ }$ & $\sqrt{ }$ & $\sqrt{ }$ & $\sqrt{ }$ & $\sqrt{ }$ \\
\hline Cayratia trifolia & & $\sqrt{ }$ & $\sqrt{ }$ & $\sqrt{ }$ & $\sqrt{ }$ & $\sqrt{ }$ & $\sqrt{ }$ & $\sqrt{ }$ & $\sqrt{ }$ & & & \\
\hline Boehovia diffusa & & & & $\sqrt{ }$ & $\sqrt{ }$ & $\sqrt{ }$ & $\sqrt{ }$ & $\sqrt{ }$ & $\sqrt{ }$ & $\sqrt{ }$ & & \\
\hline Ipomea eriocarpa & & & & $\sqrt{ }$ & $\sqrt{ }$ & $\sqrt{ }$ & $\sqrt{ }$ & $\sqrt{ }$ & $\sqrt{ }$ & $\sqrt{ }$ & & \\
\hline Tribulus sp. & & & & $?$ & $?$ & & & & & & & \\
\hline \multicolumn{13}{|l|}{ SEEDS \& NUTS } \\
\hline Acacia bidwillii & & & & & & & & $\sqrt{ }$ & $\sqrt{ }$ & $\sqrt{ }$ & $\sqrt{ }$ & \\
\hline Hakea arborescens & $?$ & & & & & & & & & & & $?$ \\
\hline \multicolumn{13}{|l|}{ SWEET FLOWERS } \\
\hline Melaleuca sp. & & & & & & $\sqrt{ }$ & $\sqrt{ }$ & $\sqrt{ }$ & $\sqrt{ }$ & $\sqrt{ }$ & $\sqrt{ }$ & \\
\hline Hakea arborescens & & & & $\sqrt{ }$ & $\sqrt{ }$ & $\sqrt{ }$ & $\sqrt{ }$ & $\sqrt{ }$ & $\sqrt{ }$ & & & \\
\hline Heteropogon sp. & & & $\sqrt{ }$ & $\sqrt{ }$ & $\sqrt{ }$ & & & & & & & \\
\hline \multicolumn{13}{|l|}{ FOLIAGE \& SHOOTS } \\
\hline Acacia bidwillii & $\sqrt{ }$ & $\sqrt{ }$ & $\sqrt{ }$ & $\sqrt{ }$ & $\sqrt{ }$ & $\sqrt{ }$ & $\sqrt{ }$ & $\sqrt{ }$ & $\sqrt{ }$ & $\sqrt{ }$ & $\sqrt{ }$ & $\sqrt{ }$ \\
\hline \multicolumn{13}{|l|}{ FRUITS } \\
\hline Cymbidium calycalatum & $?$ & $?$ & $?$ & $?$ & $?$ & $?$ & $?$ & $?$ & $?$ & $?$ & $?$ & $?$ \\
\hline Grewia retusifolia & & & $\sqrt{ }$ & $\sqrt{ }$ & $\sqrt{ }$ & & & & & & & \\
\hline Santalum lanceolatum & & & & & & & & & $\sqrt{ }$ & $\sqrt{ }$ & $\sqrt{ }$ & \\
\hline Terminalia platyptera & & & & & & & & & & & $\sqrt{ }$ & $\sqrt{ }$ \\
\hline
\end{tabular}

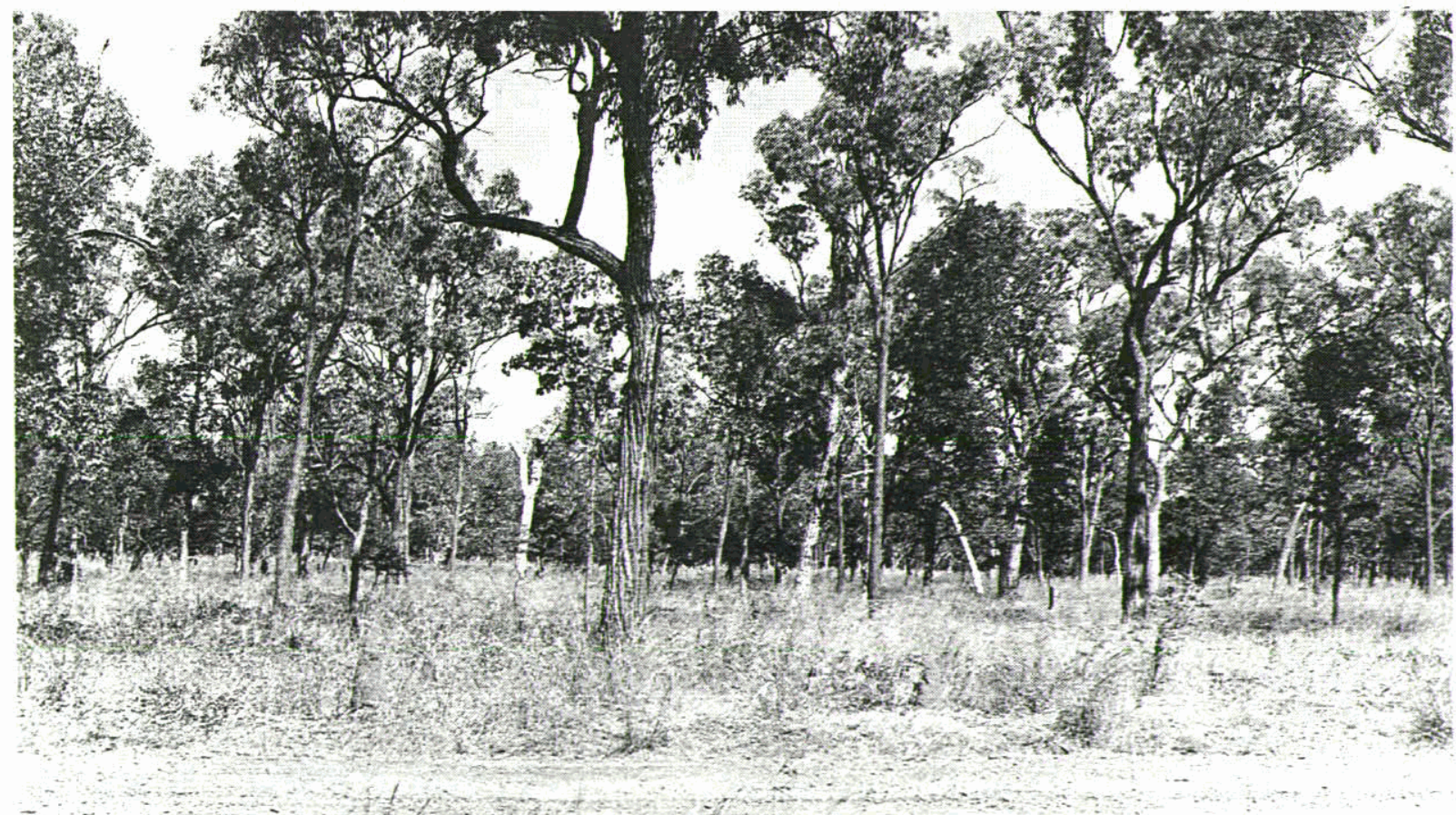

Figure 4. The Plains. 


\section{The Hills}

The Hills cover $99 \mathrm{~km}^{2}$, or $68 \%$ of the study region, including most of the undulating lands (Fig. 5). Slope gradients range from $c .2^{\circ}$ to $20^{\circ}$, and altitudes range from $440 \mathrm{~m} \mathrm{ASL}$ in the east to $240 \mathrm{~m}$ in the west. The most common plants are Eucalyptus cullenii, E. dichromophloia, Erythrophloeum chlorostachys, Heteropogon contortus and Themeda australis. Edible plants include 24 taxa, including tubers, seeds and nuts, sweet flowers and fruits (Table 3). Drainage in the Hills ranges from poor at lower topographic levels to very good on the upper slopes.

The Hills are predominantly of the Lower Devonian Mt. Garnet and Chillagoe Formations, consisting of cherts, greywackes, quartzites, siltstones and conglomerates. In the southwestern portions of the study area, granites and quartzites of the Precambrian Dargalong Metamorphics are also found. This latter Formation is separated from the eastern Chillagoe Formation by the Palmerville Fault Line (de Keyser \& Wolff 1964).

Table 3. Edible plants growing on the Hills. $\sqrt{ }=$ present, $?=$ probably present.

\begin{tabular}{|c|c|c|c|c|c|c|c|c|c|c|c|c|}
\hline Plant Resource & Jan & Feb & Mar & Apr & May & June & July & Aug & Sep & Oct & Nov & Dec \\
\hline \multicolumn{13}{|l|}{ TUBERS } \\
\hline $\begin{array}{l}\text { Brachychiton } \\
\text { paradoxus }\end{array}$ & $\sqrt{ }$ & $\sqrt{ }$ & $\sqrt{ }$ & $\sqrt{ }$ & $\sqrt{ }$ & $\sqrt{ }$ & $\sqrt{ }$ & $\sqrt{ }$ & $\sqrt{ }$ & $\sqrt{ }$ & $\sqrt{ }$ & $\sqrt{ }$ \\
\hline Acacia bidwillii & $?$ & $?$ & $?$ & $?$ & $?$ & $?$ & $?$ & $?$ & $?$ & $?$ & $?$ & $?$ \\
\hline Cochlospermum sp. & $?$ & $?$ & $?$ & $?$ & $?$ & $?$ & $?$ & $?$ & $?$ & $?$ & $?$ & $?$ \\
\hline Cayratia trifolia & & $\sqrt{ }$ & $\sqrt{ }$ & $\sqrt{ }$ & $\sqrt{ }$ & $\sqrt{ }$ & $\sqrt{ }$ & $\sqrt{ }$ & $\sqrt{ }$ & & & \\
\hline Boehavia diffusa & & & & $\sqrt{ }$ & $\sqrt{ }$ & $\sqrt{ }$ & $\sqrt{ }$ & $\sqrt{ }$ & $\sqrt{ }$ & $\sqrt{ }$ & & \\
\hline \multicolumn{13}{|l|}{ SEEDS \& NUTS } \\
\hline $\begin{array}{l}\text { Brachychiton } \\
\text { paradoxus }\end{array}$ & & & $\sqrt{ }$ & $\sqrt{ }$ & $\sqrt{ }$ & $\sqrt{ }$ & $\sqrt{ }$ & $\sqrt{ }$ & $\sqrt{ }$ & $\sqrt{ }$ & & \\
\hline Acacia bidwillii & & & & & & & & $\sqrt{ }$ & $\sqrt{ }$ & $\sqrt{ }$ & & \\
\hline Crotalaria sp. & & & $?$ & $?$ & $?$ & & & & & & & \\
\hline \multicolumn{13}{|l|}{ SWEET FLOWERS } \\
\hline Grevillea glauca & & & & & & & & $?$ & $?$ & & & \\
\hline $\begin{array}{l}\text { Grevillea } \\
\text { mimosoides }\end{array}$ & & & & & & & & $?$ & $?$ & & & \\
\hline Grevillea parallela & & & & & & & & $\sqrt{ }$ & $\sqrt{ }$ & & & \\
\hline $\begin{array}{l}\text { Grevillea } \\
\text { polystachya }\end{array}$ & & & & & & & & $?$ & $?$ & & & \\
\hline Persoonia faleata & & & & & & & & & $\sqrt{ }$ & $\sqrt{ }$ & $\sqrt{ }$ & \\
\hline \multicolumn{13}{|l|}{ FRUITS } \\
\hline $\begin{array}{l}\text { Cymbidium } \\
\text { calycalatum }\end{array}$ & $?$ & $?$ & $?$ & $?$ & $?$ & $?$ & $?$ & $?$ & $?$ & $?$ & $?$ & $?$ \\
\hline Grewia retusifolia & & & $\sqrt{ }$ & $\sqrt{ }$ & $\sqrt{ }$ & & & & & & & \\
\hline Capparis canescens & & & & & & $\sqrt{ }$ & $\sqrt{ }$ & $\sqrt{ }$ & & & & \\
\hline Cayratia trifolia & & $\sqrt{ }$ & $\sqrt{ }$ & $\sqrt{ }$ & & & & & & & & \\
\hline Exocarpus latifolius & $?$ & $?$ & $?$ & $?$ & $?$ & $?$ & $?$ & $?$ & $?$ & $?$ & $?$ & $?$ \\
\hline Gardenia ochreata & & & & & & $\sqrt{ }$ & $?$ & $?$ & & & & \\
\hline Persoonia faleata & $\sqrt{ }$ & $\sqrt{ }$ & $\sqrt{ }$ & & & & & & & & $\sqrt{ }$ & $\sqrt{ }$ \\
\hline $\begin{array}{l}\text { Petalostigma } \\
\text { pubescens }\end{array}$ & & & & & $\sqrt{ }$ & $\sqrt{ }$ & $\sqrt{ }$ & & & & & \\
\hline Planchonella sp. & & & & & & & & $\sqrt{ }$ & $\sqrt{ }$ & $\sqrt{ }$ & & \\
\hline Planchonia careya & & & & & & & & & $\sqrt{ }$ & $\sqrt{ }$ & $\sqrt{ }$ & \\
\hline Pouteria sericea & & & & $\sqrt{ }$ & $\sqrt{ }$ & & & & & & & \\
\hline
\end{tabular}

\section{The Riverine Zone}

The study area is drained by a dentritic system of mainly temporary creeks and rivers. The major waterway is the Walsh River to the immediate north of the study region, which carries waters from the major creeks westward to the Gulf of Carpentaria. Although most of the creeks and rivers dry up completely during the dry season, permanent springs occur, albeit sporadically.

The Riverine Zone forms a narrow belt along most water courses, varying in width from $10 \mathrm{~m}$ to $100 \mathrm{~m}$ (Fig. 6). It accounts for $7 \mathrm{~km}^{2}(5 \%)$ of the study region. The vegetation of the Riverine Zone is often distinct from that of the surrounding Plains and Hills, and include Tristania grandiflora, Melaleuca bracteata, M. argentia and Pandanus spp.. Fifteen edible plant species are known from the Riverine Zone, including edible fungi, seeds and nuts, sweet flowers, foliage and shoots and fruits (Table 4). 


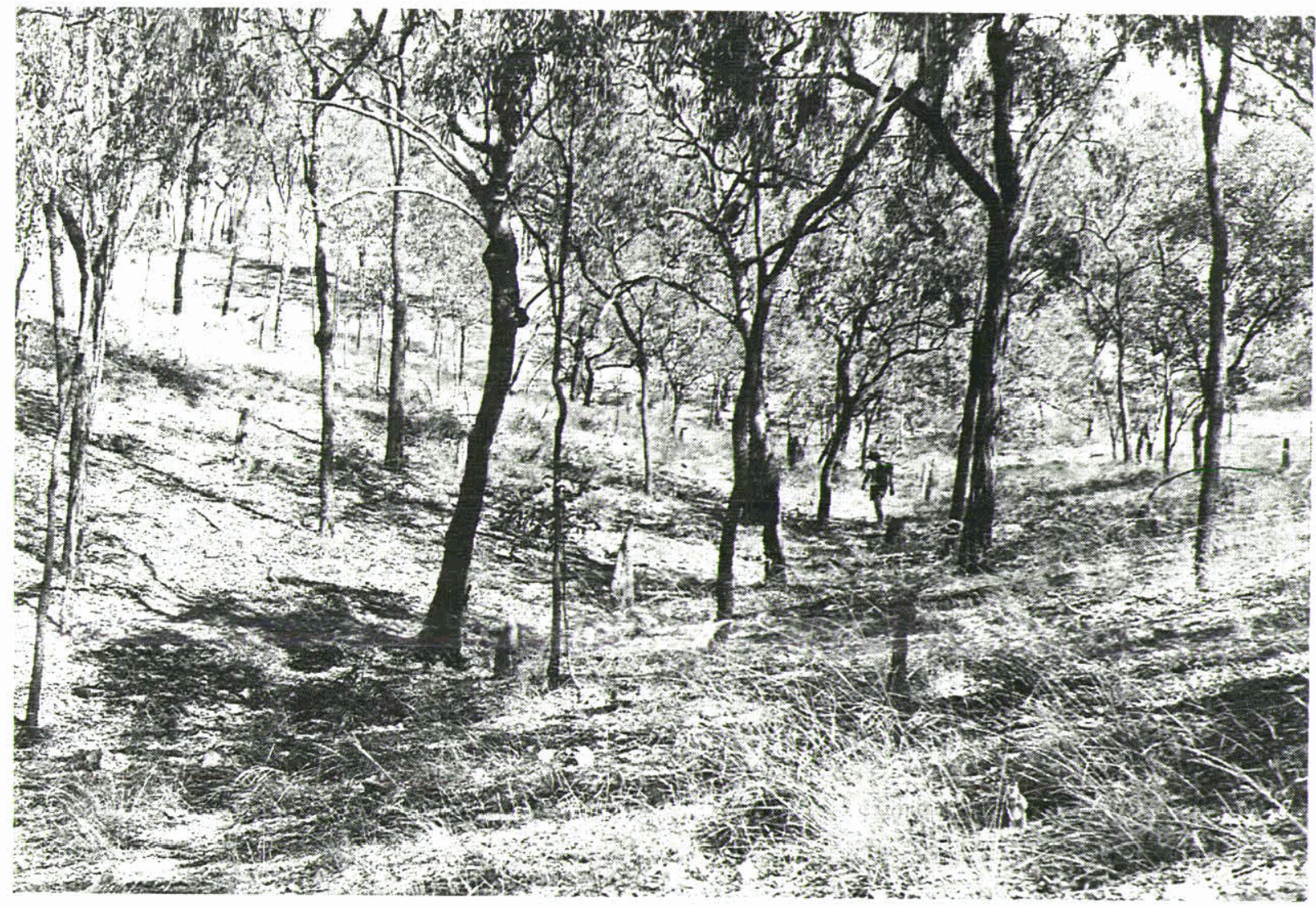

Figure 5. The Hills.

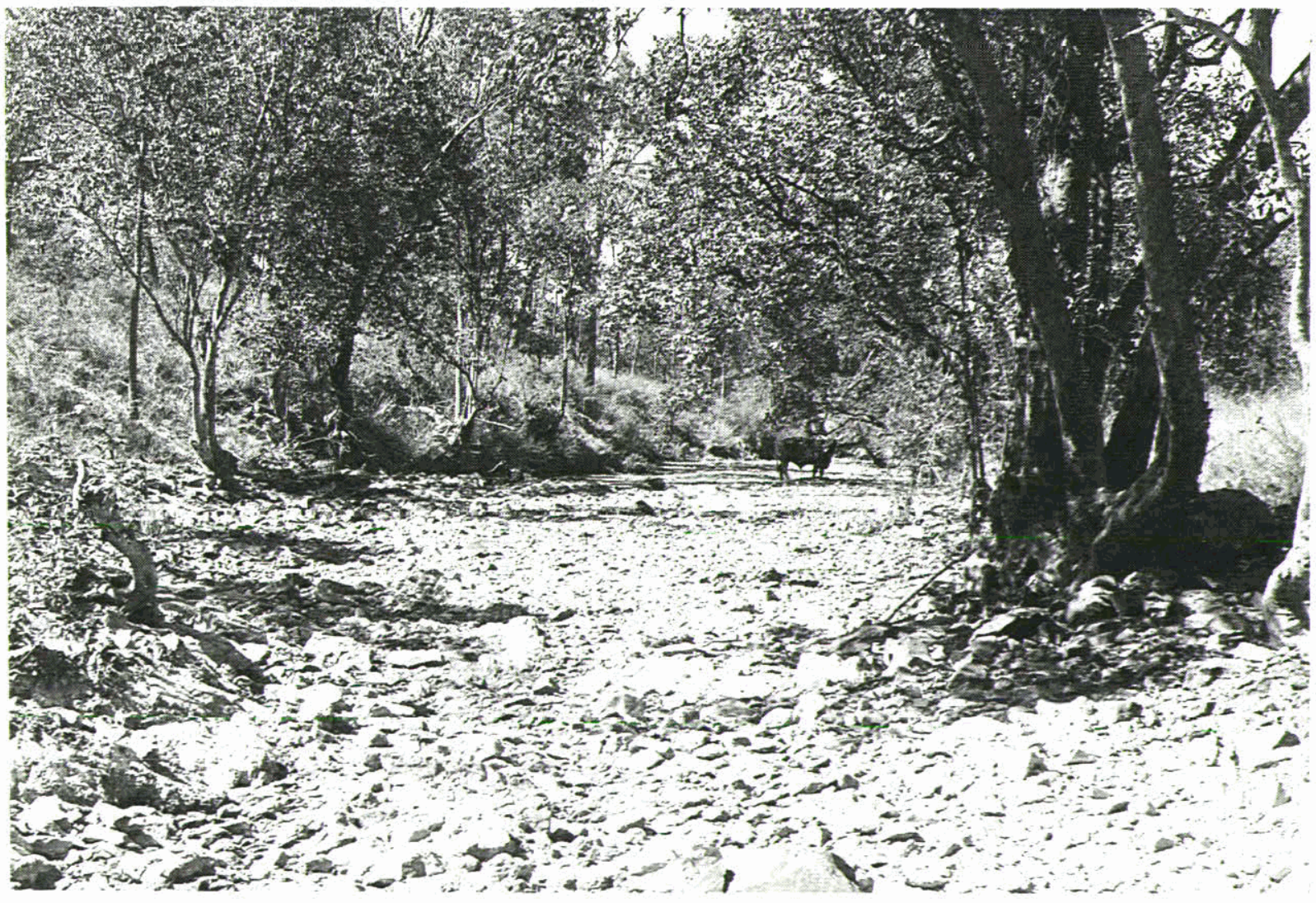

Figure 6. The Riverine Zone. 
Table 4. Edible plants growing in the Riverine Zone. $\sqrt{ }=$ present, $?=$ probably present.

\begin{tabular}{|c|c|c|c|c|c|c|c|c|c|c|c|c|}
\hline Plant Resource & Jan & Feb & Mar & Apr & May & June & July & Aug & Sep & Oct & Nov & Dec \\
\hline \multicolumn{13}{|l|}{ FUNGI } \\
\hline Spp. unknown & $\sqrt{ }$ & $\sqrt{ }$ & $\sqrt{ }$ & & & & & & & & $\sqrt{ }$ & $\sqrt{ }$ \\
\hline \multicolumn{13}{|l|}{ SEEDS \& NUTS } \\
\hline $\begin{array}{l}\text { Canarium } \\
\text { custralianum }\end{array}$ & $\sqrt{ }$ & $\sqrt{ }$ & $\sqrt{ }$ & $\sqrt{ }$ & $\sqrt{ }$ & & & & & $\sqrt{ }$ & $\sqrt{ }$ & $\sqrt{ }$ \\
\hline Pandamus sp. & $\sqrt{ }$ & & & & & & & $\sqrt{ }$ & $\sqrt{ }$ & $\sqrt{ }$ & $\sqrt{ }$ & $\sqrt{ }$ \\
\hline \multicolumn{13}{|c|}{ SWEET FLOWERS } \\
\hline Melaleuca sp. & & & & & & & & $\sqrt{ }$ & $\sqrt{ }$ & $\sqrt{ }$ & & \\
\hline $\begin{array}{l}\text { Melaleuca } \\
\text { argentia }\end{array}$ & & & & & & $\sqrt{ }$ & $\sqrt{ }$ & $\sqrt{ }$ & $\sqrt{ }$ & $\sqrt{ }$ & $\sqrt{ }$ & \\
\hline Melaleuca sp. & & & & $\sqrt{ }$ & & & & & & & & \\
\hline Melaleuca sp. & & & & & & & & $\sqrt{ }$ & $\sqrt{ }$ & $\sqrt{ }$ & & \\
\hline Melaleuca sp. & $\sqrt{ }$ & $\sqrt{ }$ & $\sqrt{ }$ & & & & & & & & & $\sqrt{ }$ \\
\hline \multicolumn{13}{|c|}{ FOLIAGE \& SHOOTS } \\
\hline Portulaca sp. & $?$ & $?$ & $?$ & $?$ & $?$ & $?$ & $?$ & $?$ & $?$ & $?$ & $?$ & $?$ \\
\hline \multicolumn{13}{|l|}{ FRUITS } \\
\hline $\begin{array}{l}\text { Canarium } \\
\text { australianum }\end{array}$ & $\sqrt{ }$ & $\sqrt{ }$ & $\sqrt{ }$ & $\sqrt{ }$ & $\sqrt{ }$ & & & & & $\sqrt{ }$ & $\sqrt{ }$ & $\sqrt{ }$ \\
\hline Ficus opposita & & & & & & & & & & $\sqrt{ }$ & $\sqrt{ }$ & $\sqrt{ }$ \\
\hline Ficus racemosa & & & & & & & & & & $?$ & $?$ & $?$ \\
\hline Morinda oliefera & $\sqrt{ }$ & $\sqrt{ }$ & & & & & & & & & & \\
\hline $\begin{array}{l}\text { Syzigium } \\
\text { eucalyptoides }\end{array}$ & $\sqrt{ }$ & & & & & & & & & & & $\sqrt{ }$ \\
\hline $\begin{array}{l}\text { Terminalia } \\
\text { platyphylla }\end{array}$ & & & & & & & & & & & $\sqrt{ }$ & $\sqrt{ }$ \\
\hline
\end{tabular}

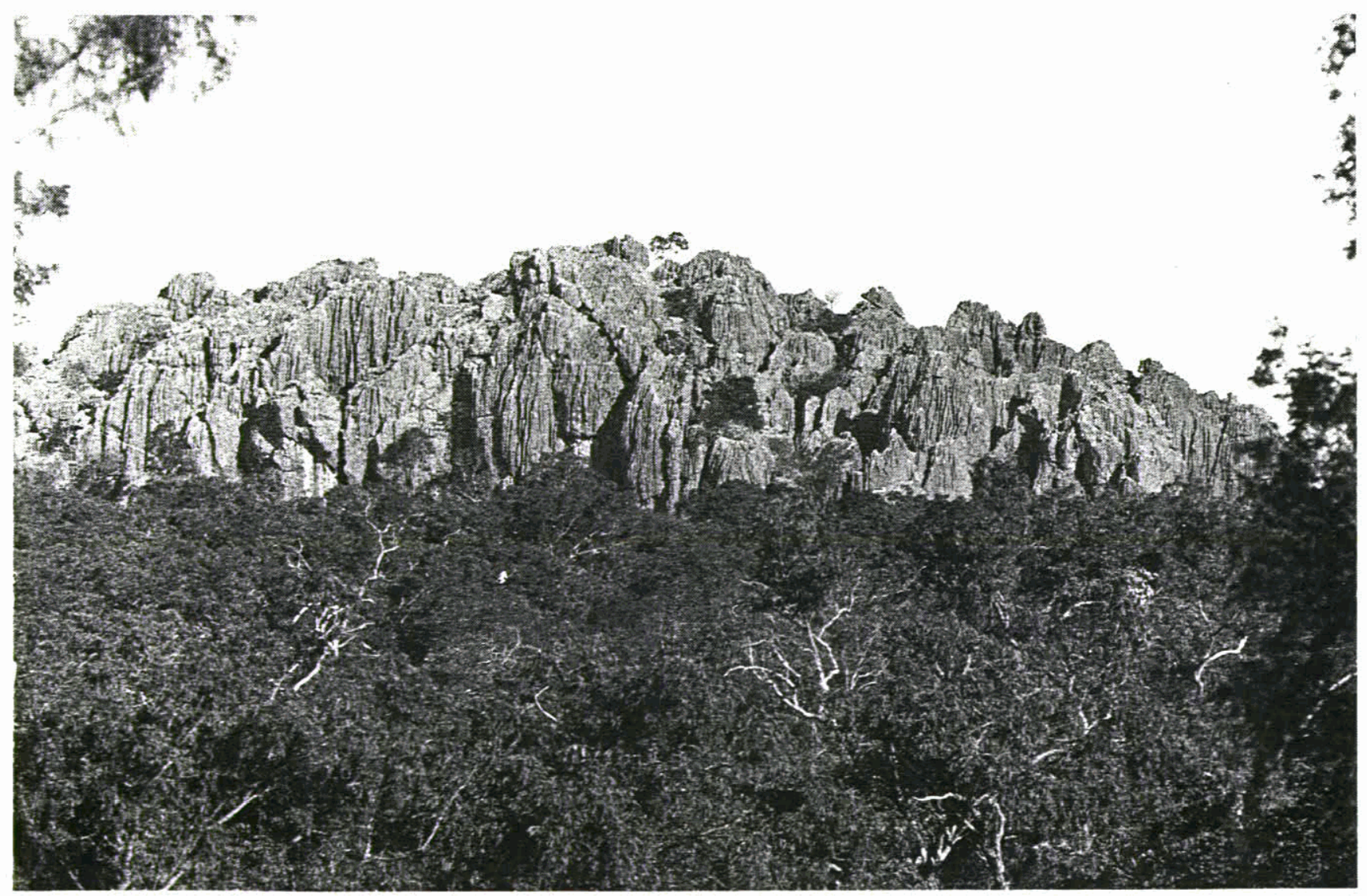

Figure 7. The Limestone Zone. 


\section{The Limestone Karst Towers}

More than any other land unit, the Limestone Karst Towers (hereafter called the Limestone Zone) set the Chillagoe region apart from the surrounding landscape (Fig. 7). These are massive Lower Devonian-Upper Silurian fossiliferous reef-limestone outcrops which have been uplifted above the surrounding landscape. They rise up to $100 \mathrm{~m}$ above the Plains, and are mostly devoid of vegetation except on their surrounding pediments where microphyll vine thickets abound. Caves and rockshelters are common throughout this land unit. While Brachychiton spp., Ficus spp. and Lysiphyllum hookeri predominate, the limestone pediments support a rich diversity of edible fruiting plants (Table 5). It boasts 15 known taxa of edible tubers, eight of seeds and nuts, two of sweet flowers, four of edible shoots and foliage, 41 edible fruit species as well as an unknown quantity of edible fungi. Of these, it is the fruit that make this land unit stand apart from the Plains, Hills and Riverine Zone. Some of these fruits are available year-round, although most are restricted to the wet season.

Limestone Karst Towers account for $4 \mathrm{~km}^{2}(3 \%)$ of the study region.

Table 5. Edible plants growing on the Limestone Karst Towers. $\sqrt{ }=$ present, $?=$ probably present.

\begin{tabular}{|c|c|c|c|c|c|c|c|c|c|c|c|c|}
\hline Plant Resource & Jan & Feb & Mar & Apr & May & June & July & Aug & Sep & Oct & Nov & Dec \\
\hline \multicolumn{13}{|l|}{ FUNGI } \\
\hline Spp. unknown & $\sqrt{ }$ & $\sqrt{ }$ & $\sqrt{ }$ & & & & & & & & & \\
\hline \multicolumn{13}{|l|}{ SEEDS \& NUTS } \\
\hline Canarium australianum & $\sqrt{ }$ & $\sqrt{ }$ & $\sqrt{ }$ & $\sqrt{ }$ & $\sqrt{ }$ & & & & & $\sqrt{ }$ & $\sqrt{ }$ & $\sqrt{ }$ \\
\hline Brachychiton australe & & & & & & & & $\sqrt{ }$ & $\sqrt{ }$ & $\sqrt{ }$ & & \\
\hline Acacia bidwillii & & & & & & & & $\sqrt{ }$ & $\sqrt{ }$ & $\sqrt{ }$ & & \\
\hline Brachychiton sp. & & & & & & & & $\sqrt{ }$ & $\sqrt{ }$ & $\sqrt{ }$ & & \\
\hline Crotalaria sp. & & $?$ & $?$ & $?$ & & & & & & & & \\
\hline Crotalaria sp. & & $?$ & $?$ & $?$ & & & & & & & & \\
\hline Hibiscus mircukensis & & & $\sqrt{ }$ & $\sqrt{ }$ & & & & & & & & \\
\hline Portulaca sp. & & $\sqrt{ }$ & $\sqrt{ }$ & $\sqrt{ }$ & & & & & & & & \\
\hline \multicolumn{13}{|l|}{ SWEET FLOWERS } \\
\hline Grevillea polystachya & & & & & & & & $?$ & $?$ & & & \\
\hline Lysiphyllum hookeri & & & & & & & & & $\sqrt{ }$ & $\sqrt{ }$ & $\sqrt{ }$ & \\
\hline \multicolumn{13}{|l|}{ FOLIAGE \& SHOOTS } \\
\hline Cissus sp. & $\sqrt{ }$ & $\sqrt{ }$ & $\sqrt{ }$ & $\sqrt{ }$ & $\sqrt{ }$ & $\sqrt{ }$ & $\sqrt{ }$ & $\sqrt{ }$ & $\sqrt{ }$ & $\sqrt{ }$ & $\sqrt{ }$ & $\sqrt{ }$ \\
\hline Dodonea platyptera & $\sqrt{ }$ & $\sqrt{ }$ & $\sqrt{ }$ & $\sqrt{ }$ & $\sqrt{ }$ & $\sqrt{ }$ & $\sqrt{ }$ & $\sqrt{ }$ & $\sqrt{ }$ & $\sqrt{ }$ & $\sqrt{ }$ & $\sqrt{ }$ \\
\hline Erythrina vespertilio & $\sqrt{ }$ & $\sqrt{ }$ & $\sqrt{ }$ & $\sqrt{ }$ & $\sqrt{ }$ & $\sqrt{ }$ & $\sqrt{ }$ & $\sqrt{ }$ & $\sqrt{ }$ & $\sqrt{ }$ & $\sqrt{ }$ & $\sqrt{ }$ \\
\hline Ficus platypoda & & & & & & & & & & $\sqrt{ }$ & $\sqrt{ }$ & $\sqrt{ }$ \\
\hline \multicolumn{13}{|l|}{ TUBERS } \\
\hline Amplocissus acetosus & & & & & & & & $\sqrt{ }$ & $\sqrt{ }$ & $\sqrt{ }$ & & \\
\hline Amplocissus sp. & & & & & & & & $\sqrt{ }$ & $\sqrt{ }$ & $\sqrt{ }$ & & \\
\hline Brachychiton australe & $?$ & $?$ & $?$ & $?$ & $?$ & $?$ & $?$ & $?$ & $?$ & $?$ & $?$ & $?$ \\
\hline Acacia bidwillii & $?$ & $?$ & $?$ & $?$ & $?$ & $?$ & $?$ & $?$ & $?$ & $?$ & $?$ & $?$ \\
\hline Brachychiton sp. & $?$ & $?$ & $?$ & $?$ & $?$ & $?$ & $?$ & $?$ & $?$ & $?$ & $?$ & $?$ \\
\hline Coyratia grandifolia & & $?$ & $?$ & $?$ & $?$ & $?$ & & & & & & \\
\hline Cayratia trifolia & & $\sqrt{ }$ & $\sqrt{ }$ & $\sqrt{ }$ & $\sqrt{ }$ & $\sqrt{ }$ & $\sqrt{ }$ & $\sqrt{ }$ & $\sqrt{ }$ & & & \\
\hline \multicolumn{13}{|l|}{ Cissus opaca } \\
\hline \multicolumn{13}{|l|}{ Cissus sp. } \\
\hline Cochlospermum sp. & $?$ & $?$ & $?$ & $?$ & $?$ & $?$ & $?$ & $?$ & $?$ & $?$ & $?$ & $?$ \\
\hline Erythrina vespertilio & $\sqrt{ }$ & $\sqrt{ }$ & $\sqrt{ }$ & $\sqrt{ }$ & $\sqrt{ }$ & $\sqrt{ }$ & $\sqrt{ }$ & $\sqrt{ }$ & $\sqrt{ }$ & $\sqrt{ }$ & $\sqrt{ }$ & $\sqrt{ }$ \\
\hline Ipomea sp. & & & & $\sqrt{ }$ & $\sqrt{ }$ & $\sqrt{ }$ & $\sqrt{ }$ & $\sqrt{ }$ & $\sqrt{ }$ & $\sqrt{ }$ & & \\
\hline Portulaca lutea & & & $?$ & $?$ & $?$ & & & & & & & \\
\hline Portulaca napiformis & & & $?$ & $?$ & $?$ & & & & & & & \\
\hline Vigna canescens & & & & $\sqrt{ }$ & $\sqrt{ }$ & & & & & & & \\
\hline \multicolumn{13}{|l|}{ FRUITS } \\
\hline Amplocissus acetosus & & & & & & $\sqrt{ }$ & $\sqrt{ }$ & $\sqrt{ }$ & $\sqrt{ }$ & $\sqrt{ }$ & $\sqrt{ }$ & \\
\hline Amplocissus sp. & & & & & & $\sqrt{ }$ & $\sqrt{ }$ & $\sqrt{ }$ & $\sqrt{ }$ & $\sqrt{ }$ & $\sqrt{ }$ & \\
\hline Antidesma parviflorum & & & & $\sqrt{ }$ & $?$ & $?$ & & & & & & \\
\hline Canarium australiamum & $\sqrt{ }$ & $\sqrt{ }$ & $\sqrt{ }$ & $\sqrt{ }$ & $\sqrt{ }$ & & & & & $\sqrt{ }$ & $\sqrt{ }$ & $\sqrt{ }$ \\
\hline
\end{tabular}




\begin{tabular}{|c|c|c|c|c|c|c|c|c|c|c|c|c|}
\hline Capparis canescens & & & & & & $\sqrt{ }$ & $\sqrt{ }$ & $\sqrt{ }$ & & & & \\
\hline Capparis lassiantha & & & & & & $\sqrt{ }$ & $\sqrt{ }$ & $\sqrt{ }$ & & & & \\
\hline Carissa ovata & & & & $\sqrt{ }$ & $\sqrt{ }$ & $\sqrt{ }$ & $\sqrt{ }$ & $\sqrt{ }$ & $\sqrt{ }$ & $\sqrt{ }$ & & \\
\hline Cayratia grandifolia & & $?$ & $?$ & $?$ & & & & & & & & \\
\hline Cayratia trifolia & & $\sqrt{ }$ & $\sqrt{ }$ & $\sqrt{ }$ & & & & & & & & \\
\hline Cissus hastata & & & & & & $\sqrt{ }$ & $\sqrt{ }$ & $\sqrt{ }$ & $\sqrt{ }$ & $\sqrt{ }$ & $\sqrt{ }$ & \\
\hline Cissus sp. & & & & & & $\sqrt{ }$ & $\sqrt{ }$ & $\sqrt{ }$ & $\sqrt{ }$ & $\sqrt{ }$ & $\sqrt{ }$ & \\
\hline Citriobutus spinescens & & & $\sqrt{ }$ & $\sqrt{ }$ & $\sqrt{ }$ & & & & & & & \\
\hline Celtis paniculata & & $\sqrt{ }$ & $\sqrt{ }$ & $\sqrt{ }$ & & & & & & & & \\
\hline \multicolumn{13}{|l|}{$\begin{array}{l}\text { Clerodendrum } \\
\text { tomentosum }\end{array}$} \\
\hline Dendroanide moroides & & & & & & $\sqrt{ }$ & $\sqrt{ }$ & $\sqrt{ }$ & & & & \\
\hline Drypetes australisica & $\sqrt{ }$ & $\sqrt{ }$ & $\sqrt{ }$ & $\sqrt{ }$ & & & & & & & & \\
\hline Ficus copiosa & $?$ & & & & & & & & & $?$ & $?$ & $?$ \\
\hline Ficus infectora & $?$ & & & & & & & & & $?$ & $?$ & $?$ \\
\hline Ficus obliqua var obliqua & $?$ & & & & & & & & & $?$ & $?$ & $?$ \\
\hline $\begin{array}{l}\text { Ficus obliqua var } \\
\text { petiolaris }\end{array}$ & $?$ & & & & & & & & & $?$ & $?$ & $?$ \\
\hline Ficus opposita & & & & & & & & & & $\sqrt{ }$ & $\sqrt{ }$ & $\sqrt{ }$ \\
\hline Ficus platypoda & & & & & & & & & & $\sqrt{ }$ & $\sqrt{ }$ & $\sqrt{ }$ \\
\hline Ficus racemosa & & & & & & & & $\sqrt{ }$ & $\sqrt{ }$ & $\sqrt{ }$ & & \\
\hline Ficus virens & $?$ & & & & & & & & & $?$ & $?$ & $?$ \\
\hline $\begin{array}{l}\text { Ficus virens var } \\
\text { sublanceolata }\end{array}$ & $?$ & & & & & & & & & $?$ & $?$ & $?$ \\
\hline Grewia retusifolia & & & $\sqrt{ }$ & $\sqrt{ }$ & $\sqrt{ }$ & & & & & & & \\
\hline Hibiscus miraukensis & $?$ & $?$ & $\sqrt{ }$ & $\sqrt{ }$ & & & & & & & $?$ & $?$ \\
\hline Hibiscus sp. & $?$ & $?$ & $?$ & $?$ & & & & & & & $?$ & $?$ \\
\hline Marsdenia sp. & $\sqrt{ }$ & $\sqrt{ }$ & $\sqrt{ }$ & & & & & & & & & \\
\hline Passiflora foetida & $\sqrt{ }$ & $\sqrt{ }$ & $\sqrt{ }$ & $\sqrt{ }$ & $\sqrt{ }$ & $\sqrt{ }$ & $\sqrt{ }$ & & & & $\sqrt{ }$ & $\sqrt{ }$ \\
\hline Planchonella myrisinoides & & & & & & & & $?$ & $?$ & $?$ & & \\
\hline Planchonella cotinifolia & & & & & & & & $?$ & $?$ & $?$ & & \\
\hline Planchonella pohlmaniana & & & & & & & & $\sqrt{ }$ & $\sqrt{ }$ & $\sqrt{ }$ & & \\
\hline Planchonia careya & & & & & & & & & $\sqrt{ }$ & $\sqrt{ }$ & $\sqrt{ }$ & \\
\hline Pouteria sericea & & & & $\sqrt{ }$ & $\sqrt{ }$ & & & & & & & \\
\hline Solanum ellipticum & & & & & $\sqrt{ }$ & $\sqrt{ }$ & $\sqrt{ }$ & $\sqrt{ }$ & $\sqrt{ }$ & & & \\
\hline Syzigium eucalyptoides & $\sqrt{ }$ & & & & & & & & & & & $\sqrt{ }$ \\
\hline Terminalia chillagoensis & & & & & & & & & & & $\sqrt{ }$ & $\sqrt{ }$ \\
\hline Terminalia platyphylla & & & & & & & & & & & $\sqrt{ }$ & $\sqrt{ }$ \\
\hline Terminalia platyptera & & & & & & & & & & & $\sqrt{ }$ & $\sqrt{ }$ \\
\hline
\end{tabular}

\section{The Surveys}

All surveys employed a three-person team.. In all cases, surveying was undertaken by spreading out over a $125 \mathrm{~m}$ wide corridor, parrallel corridors being surveyed to completely survey larger areas. Each person thus covered a width of $40 \mathrm{~m}$ (see David 1984 for further details).

Two separate survey strategies were undertaken random non-stratified surveys and non-random stratified surveys. The results of each are presented separately below.

\section{The Random Non-Stratified Surveys}

A grid of $500 \times 500 \mathrm{~m}$ quadrats was superimposed over the study region in order to undertake probabilistic (random) surveys. The research area contained 580 quadrats $\left(145 \mathrm{~km}^{2}\right)$ (see Fig. 3). Each quadrat was allocated a number, and 20 of them were randomly selected for systematic surveying by picking their numbers out of a hat. Although the surveys were not stratified, all of the land units were sampled. The sampled areas total $5 \mathrm{~km}^{2}$ as listed in Table 6.

\section{The Non-Random Stratified Surveys}

Non-random (systematic) surveys were also undertaken in five selected limestone tower karsts in addition to those surveyed during the random surveys. Small areas of Plains, Hills and the Riverine Zone were also selectively surveyed, in particular the shores of the Walsh River in the extreme northwestern corner of the survey region (see Fig. 3). The total area selectively surveyed is $3.9 \mathrm{~km}^{2}$. 
Table 6. Areas surveyed and contributions of each land unit to the total study area.

\begin{tabular}{|l|c|c|c|c|c|}
\hline & $\begin{array}{c}\text { Random } \\
\text { Survey }\end{array}$ & $\begin{array}{c}\text { Non-Random } \\
\text { Survey }\end{array}$ & Total Surveyed & $\begin{array}{c}\mathbf{K m}^{2} \text { in Study } \\
\text { Area }\end{array}$ & $\begin{array}{c}\text { \% of Land Unit } \\
\text { Surveyed }\end{array}$ \\
\hline plains & $1.500 \mathrm{~km}^{2}$ & $1.500 \mathrm{~km}^{2}$ & $3.000 \mathrm{~km}^{2}$ & 35.00 & 8.6 \\
\hline hills & $3.250 \mathrm{~km}^{2}$ & $1.750 \mathrm{~km}^{2}$ & $5.000 \mathrm{~km}^{2}$ & 99.00 & 5.1 \\
\hline riverine & $0.125 \mathrm{~km}^{2}$ & $0.250 \mathrm{~km}^{2}$ & $0.375 \mathrm{~km}^{2}$ & 7.25 & 5.2 \\
\hline karst & $0.125 \mathrm{~km}^{2}$ & $0.375 \mathrm{~km}^{2}$ & $0.500 \mathrm{~km}^{2}$ & 3.75 & 13.3 \\
\hline TOTAL & $5.000 \mathrm{~km}^{2}$ & $3.875 \mathrm{~km}^{2}$ & $8.875 \mathrm{~km}^{2}$ & 145.00 & 6.1 \\
\hline
\end{tabular}

The Effects of Ground Visibility

Given that each of the four land units contained distinct vegetation communities, the ground visibility of each was assessed to determine its effects on site recovery. Visibility here refers to our ability to see the ground surface; that is, the proportion of the ground surface that is not obscured by vegetation. A series of visibility ratings was recorded for all areas surveyed, enabling a quantification of recovery rates relative to visibility to be made (Fig. 8). These visibility ratings were assessed in two ways; 1, by estimating the mean ground visibility (in percentages) of the areas surveyed, and 2 , by estimating the mean ground visibility of each site. A continuous commentary was noted on the ground visibility of the surveyed area (e.g. $0-300 \mathrm{~m}$, mean visiblity $=70 \% ; 300$ $310 \mathrm{~m}$ visibility $=80 \%$; etc.). Running notes were also made of local environmental conditions and topography. In this manner, mean ground visibility was made available for both sites and for areas immediately surrounding them.

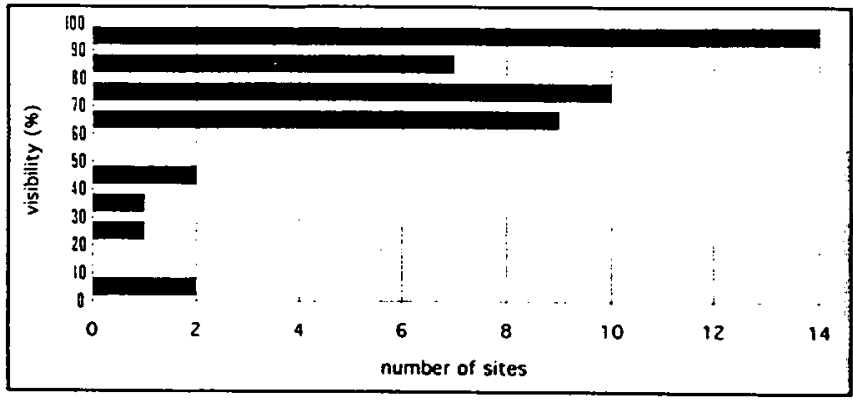

Figure 8. Number of sites recorded by $10 \%$ ground visibility intervals.

Site recovery increased dramatically above the $60 \%$ visibility mark; below which recovery rates were very low. However, areas of low ( $<60 \%)$ visibility covered only $1.75 \mathrm{~km}^{2}$ of the surveyed area, giving a recovery rate of 3.4 open sites $/ \mathrm{km}^{2}$. Visibility was $\geq 60 \%$ over most of the surveyed area $\left(7.125 \mathrm{~km}^{2}\right)$, with a mean recovery rate in high visibility areas of 5.6 open sites $/ \mathrm{km}^{2}$. Thus, recovery in high visibility areas was 1.7 times that of low visibility areas (Table 7). We now need to determine whether or not this will significantly affect the distribution of the sites recorded for the purposes of this study.

Two sets of criteria are used in the following analysis of the survey data: land units and topographic features.
The effects of ground visibility on site recovery are now assessed with these criteria in mind.

Table 7. Site discovery relative to ground visibility.

\begin{tabular}{|l|c|c|c|}
\hline & $\begin{array}{c}\text { Surveyed } \\
\text { Area }\end{array}$ & $\begin{array}{c}\text { Number of } \\
\text { Open Sites }\end{array}$ & $\begin{array}{c}\text { Site } \\
\text { Density }\end{array}$ \\
\hline $\begin{array}{l}\text { high visibility } \\
\text { areas }\end{array}$ & $7.125 \mathrm{~km}^{2}$ & 40 & $5.6 / \mathrm{km}^{2}$ \\
\hline $\begin{array}{l}\text { low visibility } \\
\text { areas }\end{array}$ & $1.750 \mathrm{~km}^{2}$ & 6 & $3.4 / \mathrm{km}^{2}$ \\
\hline TOTAL & $8.875 \mathrm{~km}^{2}$ & 46 & $5.2 / \mathrm{km}^{2}$ \\
\hline
\end{tabular}

Table 8 presents the mean ground visibility of each of the four land units surveyed. Mean visibility is similar in each case, ranging from $62.0 \%$ (Riverine Zone) to $65.0 \%$ (Limestone Karst). Similarly, the mean ground visibility of ridge tops, slopes, flat areas and creek beds are similar, ranging from $62.0 \%$ (flat areas) to $67.9 \%$ (ridge tops) (Fig. 9). On this basis, ground visibility is assumed not to have significantly affected the differential recovery of archaeological sites in the region. It is also to be noted that:

1. Four of the six sites recorded in low visibility conditions were single artefacts (CM15, 17, 18, 24). One site consisted of three artefacts (CM13). If visibility was a critical factor, we could have expected larger sites to have been preferentially recorded. That this was not the case indicates that areas of low visibility were accurately sampled, even though they may not have been sampled as accurately as areas of greater ground visibility.

2. There is no positive correlation between visibility levels and site discovery rates by environmental zone, implying that site locations should be explained by other causes.

3. $80 \%$ of the surveyed areas were of high visibility, and $87 \%$ of sites came from these areas. While a discrepancy is apparent, it is not large.

Table 8. Mean visibility ratings and site densities (open sites) by land unit.

\begin{tabular}{|l|c|c|}
\hline & Mean Visibility & Site Density \\
\hline plains & $64.0 \%$ & $5.7 / \mathrm{km}^{2}$ \\
\hline hills & $62.5 \%$ & $3.6 / \mathrm{km}^{2}$ \\
\hline riverine & $62.0 \%$ & $16.0 / \mathrm{km}^{2}$ \\
\hline karst & $65.0 \%$ & $2.0 / \mathrm{km}^{2}$ \\
\hline
\end{tabular}




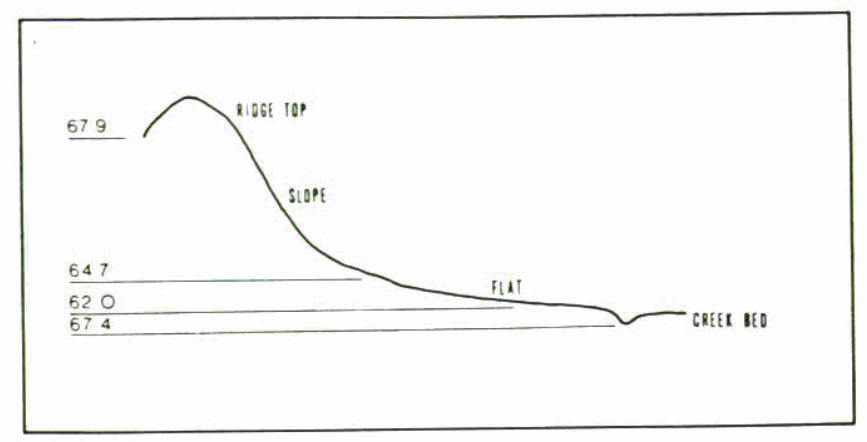

Figure 9. Mean ground visibility ratings, by topographic levels.

The above factors indicate that differential ground visibility is unlikely to account for the site patterning observed and reported in this paper.

\section{The Archaeological Sites}

All of the open sites recorded are surface or near-surface sites. Given the recent nature of most of the surface sediments (especially alluvial sediments near creeks and rivers), the site patterns observed are assumed to pertain to late Holocene times (M. Erceg, Elders Resources geologist, pers. comm. 1984). It is noted in this context that the only artefact types recovered are a single burren adze, two waisted axes and one possible elouera. As nothing is known of lithic technologies from the region, a relative chronology could not be formulated around the stone artefact assemblages.

\section{Site Types}

Sites are here identified as any evidence for human presence, be it in the form of a single artefact, surface scatter, structure, or painted or modified surface. Two sites are differentiated if they occur more than $25 \mathrm{~m}$ apart. This arbitrary measure was used for recording purposes. Single artefacts were recorded as sites as there is no reason why such locations cannot be a locus of human activity.

Four site types were identified during the surveys: quarries, open artefact scatters, rockshelters and caves. Table 9 lists the numbers of sites identified from each land unit.

Table 9. Sites recovered in each land unit. ${ }^{\star} \mathrm{CM} 46-52$ has been counted here as a single site, as this nearsurface riverine site occurs as a series of adjacent exposures ( $<25 \mathrm{~m}$ apart) that were recorded separately.

\begin{tabular}{|l|c|c|c|c|}
\hline & Quarry & $\begin{array}{c}\text { Open } \\
\text { Artefact } \\
\text { Scatter }\end{array}$ & $\begin{array}{c}\text { Rock- } \\
\text { shelter }\end{array}$ & Cave \\
\hline plains & - & 17 & - & - \\
\hline hills & 1 & 18 & - & - \\
\hline riverine & 1 & $4^{*}$ & - & - \\
\hline karst & - & 1 & 5 & 3 \\
\hline
\end{tabular}

\section{Quarries}

Two quarries were recorded (sites CM11 \& 41). These consisted of major stone outcrops. Site CM41 is a medium-grained, white quartzite block outcrop spread over an area of $c .250 \times 200 \mathrm{~m}$ (Fig. 10). The quartzite blocks have been extensively flaked (as evidenced by negative flake scars), although few flakes were found. Other (non-local) raw materials also occurred at site CM41; this site is therefore treated as both a quarry and an open artefact scatter.

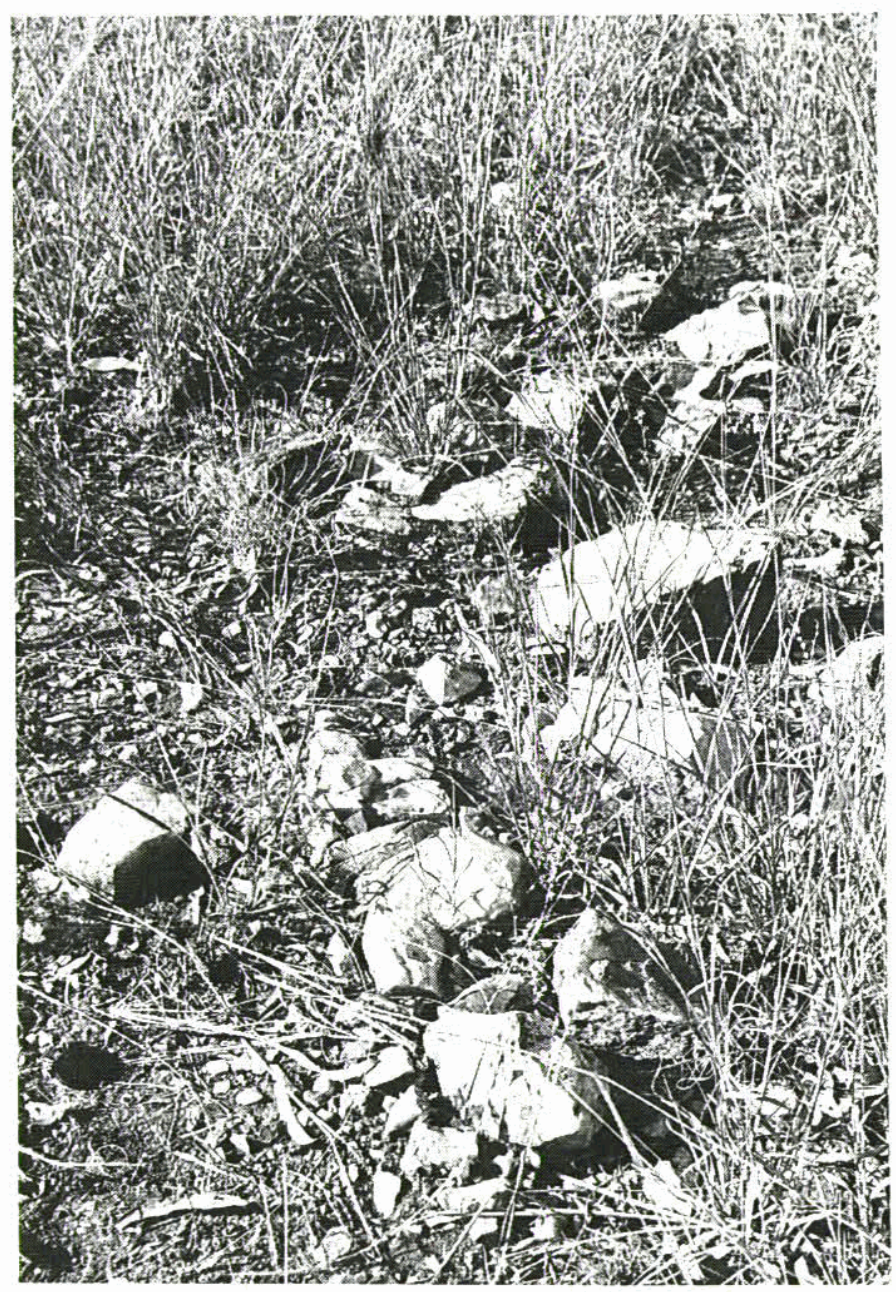

Figure 10. The quarry site, CM41.

Site CM11 occurs as an extensive deposit of large water-rolled pebbles, many of which have been flaked. CM11 is the largest site recorded in this study. It lies along the southern shores of the Walsh River, near a permanent waterhole. Stone artefacts at this site are estimated to number in the thousands. This is the only open site that was not entirely surface collected during this survey (CM41 was entirely collected except for the outcropping blocks). Like CM41, it was classified as both a quarry and an open stone artefact scatter as artefacts of foreign raw materials (two waisted axes) were found at the site.

It is to be noted that small pebbles ( $\leq 5 \mathrm{~cm}$ long) are abundant throughout the region, and indeed appear to 
have been flaked at many sites. The abundance of such raw materials in the region means that nearly every open artefact scatter recorded so far is a potential quarry, in the sense that raw materials are readily available at the site itself. I have thus identified a quarry only where stone raw materials occur as a distinct outcrop, and where this outcrop has been demonstrably exploited.

\section{Open Artefact Scatters}

Open stone artefact scatters range from single artefacts to large scatters of thousands of artefacts. Of the 46 open sites recorded, only four sites had more than 15 stone artefacts, and only one of these more than 56 artefacts. With the exception of quarries, no other types of open sites were found.

\section{Rockshelters and Caves}

Caves and rockshelters were differentiated during the surveys as the two possess different formal characteristics. Rockshelters were identified as relatively shallow overhangs where rock outcrops meet the surrounding plains or pediments. Caves were deeper intrusions into the limestone outcrops, at times extending for hundreds of metres or even kilometres into the rock outcrops (Fig. 11). No cultural material has yet been recorded in any parts of caves where sunlight does not reach.
It is also noted that members of the local Wagaman Aboriginal community were hesitant about approaching deep caves in the recent past as they are considered the abode of local Dreaming beings (David 1984). This reluctance was not evident for rockshelters.

\section{Analysis of the Open Sites}

The stone artefacts from the open sites (including the quarries) were differentiated into four categories:

1. Primary flake, being an unmodified stone flake or flaked piece. All artefacts were examined under $10 x$ magnification for evidence of use-wear and retouch. Primary flakes are here assumed to be waste biproducts of tool manufacture.

2. Modified flake, being any stone flake or flaked piece exhibiting use-wear and/or retouch. Modified flakes are deemed to have functioned as tools.

3. Chopper, being either a) a core with heavy edge modification (e.g. Hayden 1979), or b) an axe-head (Fig. 12a). Choppers are here assumed to have been probably used as wood-working implements.

4. Core, being a stone artefact from which a flake has been struck, possessing both negative flake scars and one or more striking platform, and exhibiting no positive flake scar (i.e. bulb of percussion) (Fig. 12b). A core's function is here assumed to be the manufacture of stone tools.

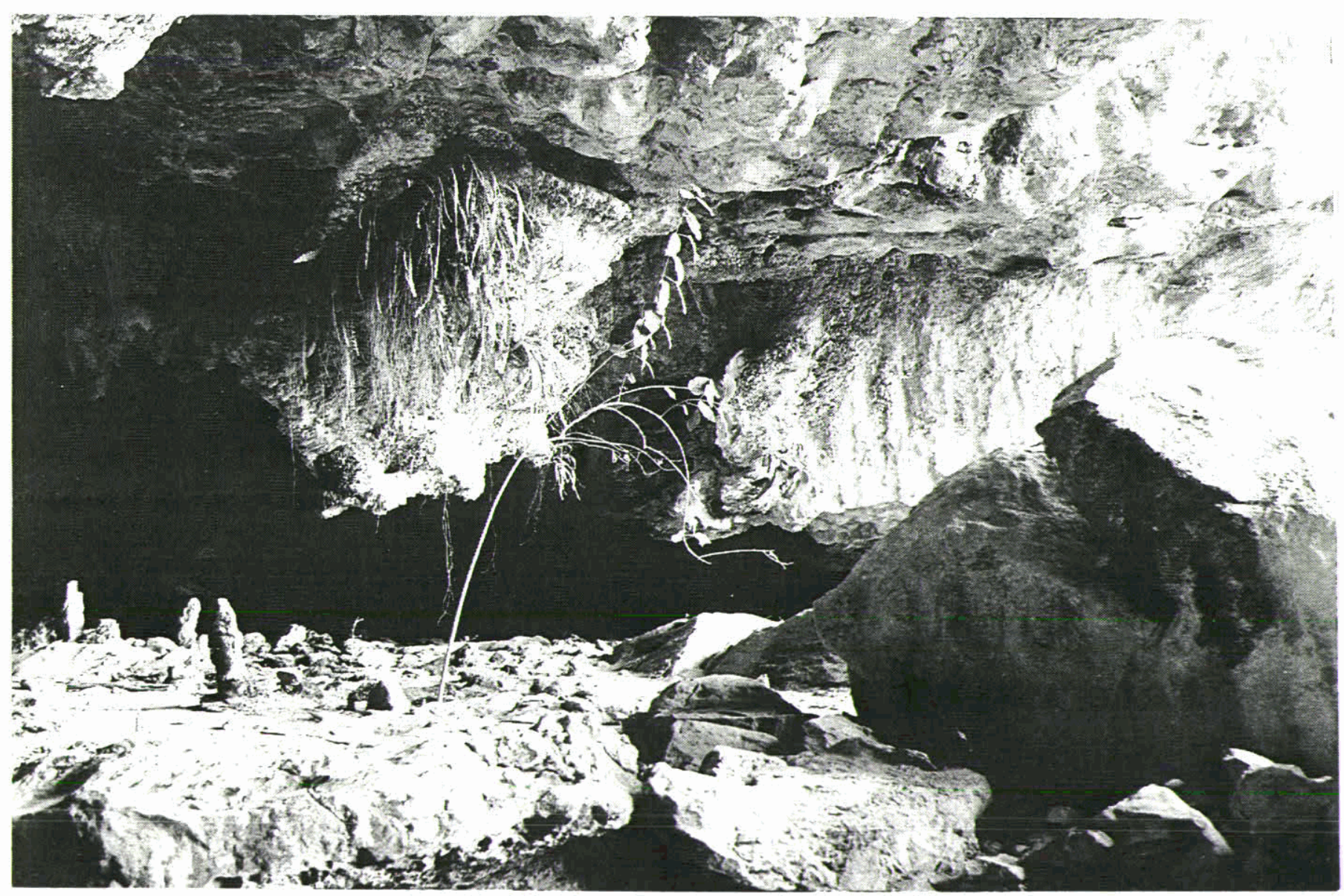

Figure 11. Fern Cave, CM26. 


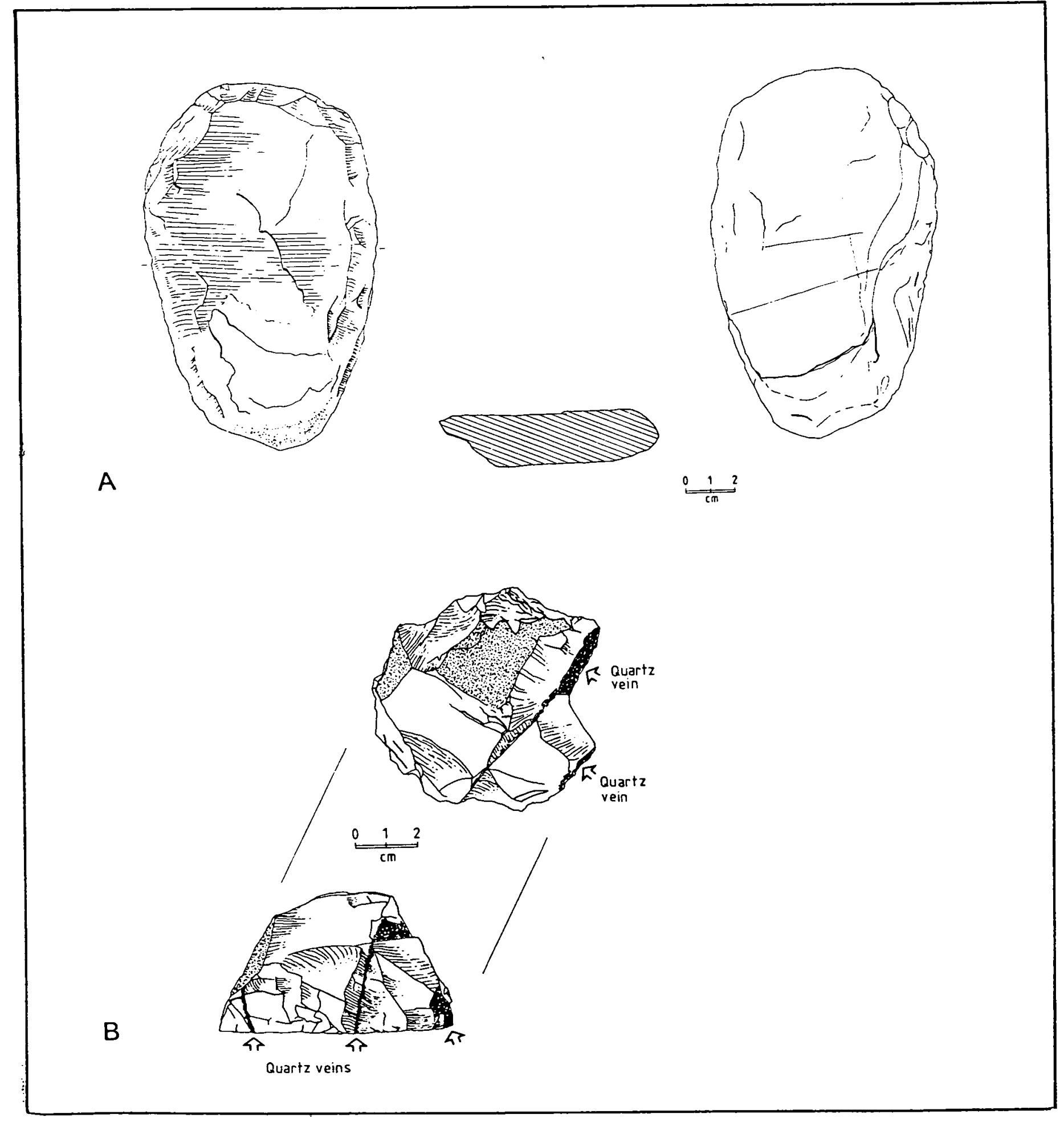

Figure 12a. Axe blank. Figure 12b Core.

In the absence of detailed analyses of edge wear and residue, the presence and combination of the above categories are used to compare and contrast activities in the open sites at a gross level. A comparative analysis is undertaken using multidimensional scaling (MDS) and
Average Linkage Cluster Analysis, and take into account both the absolute numbers of artefacts in each site as well as the proportions of the four broad artefact 'types' (Table $10)$. 
Table 10. Distribution of artefacts by open site. Site CM11 is note included as it was not totally collected.

\begin{tabular}{|c|c|c|c|c|}
\hline $\begin{array}{c}\text { Site } \\
(\mathbf{c m})\end{array}$ & $\begin{array}{c}\text { Primary } \\
\text { Flakes }\end{array}$ & $\begin{array}{c}\text { Modified } \\
\text { Flakes }\end{array}$ & Cores & Choppers \\
\hline 1 & 3 & 1 & 1 & - \\
\hline 5 & 45 & 9 & 2 & - \\
\hline 6 & 1 & 1 & 1 & - \\
\hline 7 & 32 & 6 & 2 & - \\
\hline 8 & 5 & 4 & 1 & - \\
\hline 9 & - & 2 & 1 & - \\
\hline 12 & 8 & - & 3 & - \\
\hline 13 & 1 & 2 & - & - \\
\hline 14 & 1 & 1 & - & 1 \\
\hline 15 & 2 & 1 & 1 & - \\
\hline 16 & 1 & - & - & - \\
\hline 17 & - & 1 & - & - \\
\hline 18 & - & 1 & - & - \\
\hline 19 & 5 & 5 & - & - \\
\hline 20 & & 4 & - & - \\
\hline 21 & 1 & 2 & - & - \\
\hline 22 & - & 2 & - & - \\
\hline 23 & 2 & - & - & - \\
\hline 24 & - & 1 & - & - \\
\hline 25 & 5 & 1 & - & - \\
\hline 27 & 1 & - & - & - \\
\hline 28 & - & 1 & - & - \\
\hline 29 & 1 & - & - & - \\
\hline 30 & 7 & 4 & 2 & - \\
\hline 31 & 6 & 1 & 1 & - \\
\hline 32 & 2 & 1 & - & - \\
\hline 33 & 1 & 3 & 1 & - \\
\hline 34 & 4 & - & - & - \\
\hline 35 & - & - & 1 & - \\
\hline 36 & - & 1 & - & - \\
\hline 37 & 1 & - & 1 & - \\
\hline 38 & 2 & 1 & - & - \\
\hline 39 & 1 & - & - & - \\
\hline 40 & 2 & 1 & - & - \\
\hline 41 & - & 1 & 4 & 2 \\
\hline 42 & 6 & 5 & - & - \\
\hline 44 & 3 & 1 & - & - \\
\hline 45 & - & 1 & - & - \\
\hline 46 & 1 & 3 & 1 & - \\
\hline 47 & 2 & 1 & - & - \\
\hline 48 & 2 & 2 & - & - \\
\hline 49 & - & 3 & - & - \\
\hline 50 & 1 & 2 & 2 & - \\
\hline 51 & 1 & 2 & 1 & - \\
\hline 52 & 2 & 1 & 1 & - \\
\hline
\end{tabular}

Both the MDS and the Cluster Analysis (dendrogram not shown here) reveal a relatively unclustered distribution of sites - that is, the sites cannot be differentiated into separate groups on the basis of the artefact categories employed (Fig. 13). Rather, a functional cline is indicated between sites, assuming the lithic categories and absolute numbers to be valid criteria for the measurement of gross functions as outlined above (in particular stone- and wood-working). The majority of sites are small, and appear to have witnessed a limited amount of stone and/or wood working activity. The implication is that they are mostly ephemeral sites of short duration, and that people did not return to those particular places for camping purposes once the sites were abandoned (although they may have returned to local areas). Site CM11 (which was not included in the MDS or Cluster Analysis) is likely to be an exception given its large size and abundance of stone artefacts and raw materials. The results of the multivariate statistics may also indicate that open sites may not be readily diffentiated into distinct, more or less specialised functional types in this region. Having said this, it is nevertheless interesting to note that site CM41 (the quarry) stands out as being somewhat different from the other sites.

\section{Open Sites and Environments}

Tables 11 and 12 list a number of site attributes by land unit. Site densities range from two open sites $/ \mathrm{km}^{2}$ (Limestone Zone) to 16 sites $/ \mathrm{km}^{2}$ (Riverine Zone). The following analyses are aimed at investigating if these differences are associated with other parameters, such as differences in site sizes by land unit. My aim here is to investigate the patterning of site characteristics across the four land units.

If each open site is a single-event phenomenon, as appears to be the case, the relative sizes of sites across the landscape may inform us, in general terms, about the nature of land use. In particular, it may offer hints about the sizes and permanency of settlements in each land unit. Most of the open sites indeed appear to be single-event sites, as most are small in extent, spatially well defined, and possess a small number of stone artefacts. Furthermore, with the exception of sites CM11 and CM41, few (if any) of the sites possess characteristics that differentiate them from the surrounding landscape.

It is assumed as a general rule that the longer a group stays in one place, the more stone artefacts will be deposited on the ground. Likewise, the greater the number of people, the more likely that artefacts will be deposited. It is stressed, however, that these generalisations are made to generate a model of settlement-subsistence systems for the region. This model will then need to be independently tested and refined. 


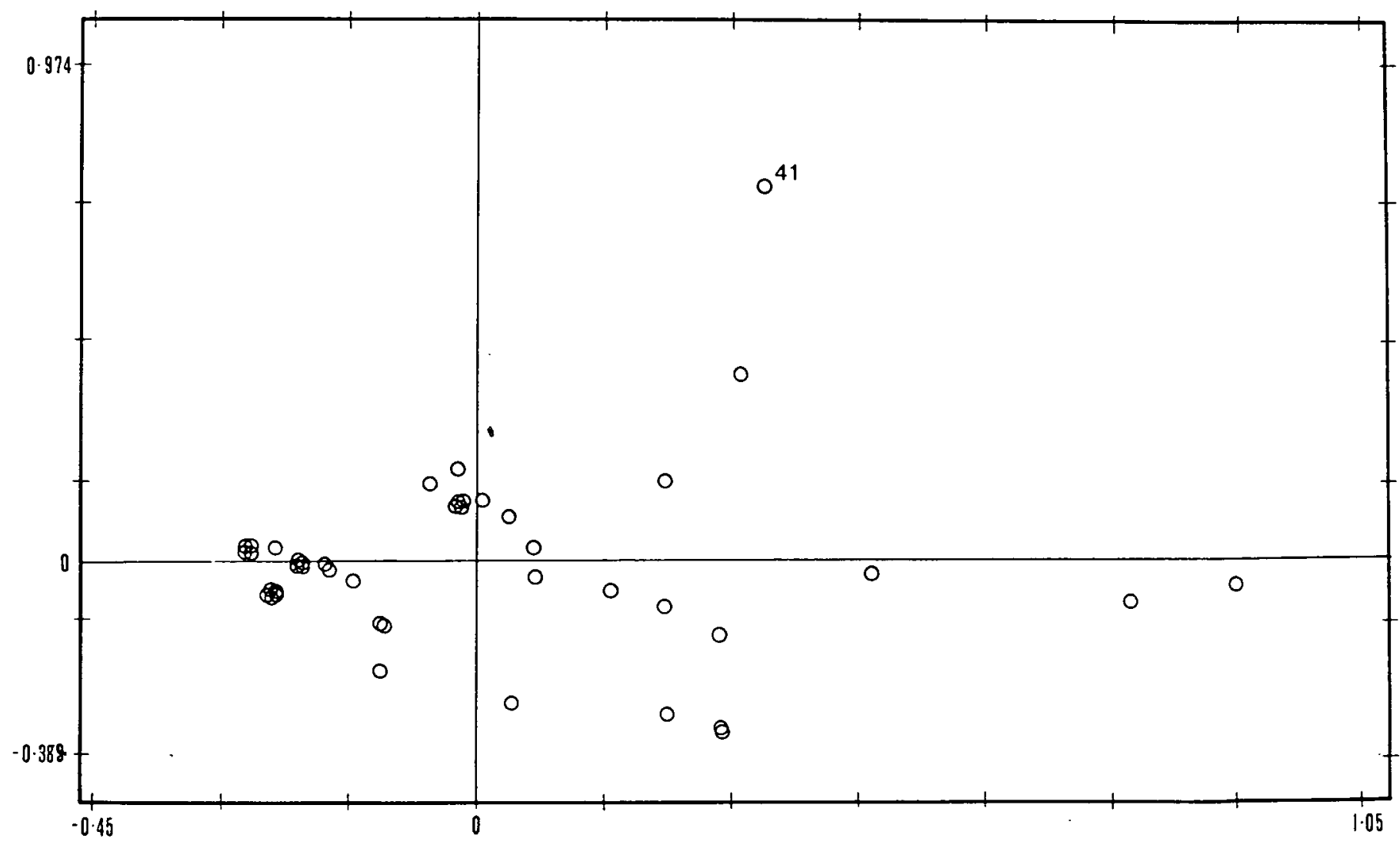

Figure 13. MDS 'map' showing statistical relationship of each site, based on stone artefact characteristics.

Table 11. Site characteristics, by land unit. ${ }^{*} \mathrm{CM} 41$ is excluded; ${ }^{* *} \mathrm{CM} 46-52$ is counted as a single site and $\mathrm{CM11}$ is excluded. Note that the Limestone Karst Tower unit consists of a single site only. It should therefore be used with caution.

\begin{tabular}{|l|c|c|c|c|c|c|c|}
\hline & $\begin{array}{c}\text { Mean } \\
\text { Area Per } \\
\text { Site }\left(\mathbf{m}^{2}\right)\end{array}$ & $\begin{array}{c}\text { Size } \\
\text { Range } \mathbf{m}^{\mathbf{2}} \text { ) }\end{array}$ & $\begin{array}{c}\text { Mean Site } \\
\text { Density } \\
(\text { Sites/ } \\
\left.\mathbf{k m}^{2}\right)\end{array}$ & $\begin{array}{c}\text { Mean \# of } \\
\text { Lithics } \\
\text { Per Site }\end{array}$ & $\begin{array}{c}\text { Range for } \\
\text { Number of } \\
\text { Lithics }\end{array}$ & $\begin{array}{c}\text { Total } \\
\text { Number of } \\
\text { Open Sites }\end{array}$ & $\begin{array}{c}\text { Mean Core+ Primary } \\
\text { Flake: Modif. Flake+ } \\
\text { Chopper Ratio }\end{array}$ \\
\hline plains & 569 & $1-2500$ & 5.7 & 8.8 & $1-56$ & 17 & $1: 0.3$ \\
\hline hills* $^{*}$ & 687 & $1-9000$ & 3.6 & 4.3 & $1-13$ & 18 & $1: 0.7$ \\
\hline river $^{*}$ & 1284 & $375-50,000$ & 12.0 & 21.0 & $4-48$ & 10 & $1: 0.2$ \\
\hline karst & 50 & 50 & 2.0 & 4.0 & 4 & 1 & $1: 0.3$ \\
\hline
\end{tabular}

Table 12. Mean artefact numbers per site.

\begin{tabular}{|l|c|c|c|c|}
\hline & Primary Flakes & Modified Flakes & Cores & Choppers \\
\hline plains & 6.2 & 1.8 & 0.8 & 0.1 \\
\hline hills & 2.1 & 1.6 & 0.5 & 0.1 \\
\hline riverine & 13.0 & 3.0 & 1.7 & 0.0 \\
\hline karst & 3.0 & 1.0 & 0.0 & 0.0 \\
\hline
\end{tabular}




\section{Results}

The trends identified above show that sites in the Riverine Zone are more common (by a factor of two- to six-fold), tend to be larger (about twice the size, on average), and contain two- to five-times more stone artefacts than in sites located in other land units. The Riverine Zone also contains the greatest proportions of stone manufacturing debris (cores + primary flakes) relative to used tools (modified flakes + choppers), indicating that stone manufacture may have been focused in the Riverine Zone. On the other hand, the Hills contain the lowest amount of debris per implement, indicating that stone tool use rather than manufacture was predominant there (relative to other land units). This pattern may indicate the predominance of transient camps in the Hills, where curated technologies were used. More permanent camps may have been located along creeks and rivers. Camps along creeks may have been larger, their greater permanence allowing more time for maintenance and manufacturing activities. It may be relevent to note that this scenario is consistent with the Hills being the poorest resource zone in the region, and the Riverine Zone one of the richest; this applies to both water and food.

\section{Seasonality and Resource Availability}

I will attempt to model seasonality of site use following two procedures:

1. The Chillagoe region undergoes marked seasonal variation in the availability of surface water. As noted above, the dry season sees a drying-out of most of the creeks and rivers. Many of these waterways have rocky beds, making the digging of wells extremely difficult and unlikely. Consequently, it is assumed that sites adjacent to temporary water sources were likely to have been used at times when surface water was available - that is, sometime between November and April. Temporary water sources are here defined as those that dry up during the early stages of the dry season.

2. Following this logic, sites located near permanent water sources may have been occupied at any time during the year, unless these sites are situated in a position where they would be inundated during the wet season. In such cases (sites located in low-lying areas near creeks), I will assume that dry season occupation is indicated.

\section{The Plains}

Seventeen open sites were found in the Plains (Table 13). Of these, 14 were situated near temporary water sources, suggesting occupation during the wet season. However, many of these were in low-lying areas, implying that they were probably not occupied at the peak of the wet season when the surrounding landscape would have been boggy. All in all, there is evidence for both early and/or late wet (CM1, 5-9, 28, 45) and dry (CM12-16, 37-40) season occupation. There is no evidence for occupation during the peak of the wet season in the flat lands of the Plains, although this does not mean that the Plains were not used. There is a considerably greater number of artefacts per site in the early and late wet season sites than there are in the dry season sites (Table 14). The implication is that dry season sites in the Plains are more ephemeral, perhaps involving smaller groups of people, than those of the early and/or late wet season. I will return to this point shortly.

\section{The Hills}

Open sites in the Hills occur both near temporary and permanent water sources. Sites CM17, 25 and 27 are situated in contexts where they would be inundated or drenched during the wet season, although the total absence of water in their vicinity implies their use when water was available (early or late wet season). Sites CM18-24, 29 and 41 are on elevated areas away from permanent water sources, implying their wet season use. Sites CM30-33 and 35-36 occur on elevated areas near permanent water, indicating that they may have been used either during the dry or the wet season (seasonality is ambiguous). There are no major differences in the numbers of stone artefacts in sites of different seasons, although the wet season sites tend to have slightly more artefacts than those of the early or late wet (Table 15). Interestingly, there are no large sites in the Hills, indicating that this land unit may not have been relied upon for large residential camps, nor for camps of fairly long duration.

\section{The Riverine Zone}

Only four open sites were recorded from the Riverine Zone (including site CM46-52, which I am treating as a single site for reasons outlined above). Sites CM11, 34 and 42 are likely to be predominantly dry season sites, given their proximity to permanent water and their likelihood of at least partial inundation during the wet season. The seasonality of site CM46-52 is ambiguous, given its geographical setting.

It is clear from Table 16 that the Riverine Zone sites tend to exhibit more stone artefacts than sites from other land units. The Riverine Zone was used during the dry season, possibly for relatively large camps and/or camps of relatively long duration around standing waterholes. Unlike in other land units, there is evidence in sites CM11 and 46-52 that people may have returned to such places many times over the years. Therefore, dry seasons in particular may have involved a return to limited numbers of water sources, whereas no such returns are evident for the wet season in either the Plains, Hills or Riverine Zone.

\section{The Limestone Zone}

Only one open site was recorded from the Limestone Zone (CM44, with four stone artefacts), although 12 other sites are located within a short distance of this land unit. Site CM44 is located on well-drained ground near a temporary water source, indicating that it may have been used during the wet season. Little can be said of occupation of this zone given the small sample size. 
Table 13. Site locational data, open sites.

\begin{tabular}{|c|c|c|c|c|c|c|}
\hline $\begin{array}{l}\text { Site } \\
\text { (cm) }\end{array}$ & Land Unit & $\begin{array}{c}\text { Metres to } \\
\text { Tempor. } \\
\text { Water }\end{array}$ & $\begin{array}{c}\text { Metres to } \\
\text { Perman. Water }\end{array}$ & $\begin{array}{l}\text { Metres to Stone } \\
\text { Raw Material }\end{array}$ & $\begin{array}{l}\text { Metres to Karst } \\
\text { Tower }\end{array}$ & Topography \\
\hline 1 & Plains & 75 & $>1000$ & 75 & 100 & flats \\
\hline 5 & Plains & 100 & $>1000$ & 0 & 50 & flats \\
\hline 6 & Plains & 200 & $>1000$ & 150 & 10 & flats \\
\hline 7 & Plains & 10 & $>1000$ & 0 & 50 & flats \\
\hline 8 & Plains & 10 & $>1000$ & 0 & 20 & flats \\
\hline 9 & Plains & 10 & $>1000$ & 0 & 5 & flats \\
\hline 11 & Riverine & 50 & 50 & 0 & $>1000$ & flats \\
\hline 12 & Plains & 100 & 350 & 0 & $>1000$ & flats \\
\hline 13 & Plains & 100 & 350 & 0 & $>1000$ & flats \\
\hline 14 & Plains & 5 & 500 & 0 & $>1000$ & flats \\
\hline 15 & Plains & 60 & 750 & 0 & $>1000$ & flats \\
\hline 16 & Plains & 2 & 1000 & 0 & $>1000$ & flats \\
\hline 17 & Hills & 15 & $>1000$ & 10 & $>1000$ & flats \\
\hline 18 & Hills & 70 & $>1000$ & 0 & $>1000$ & ridge-top \\
\hline 19 & Hills & 25 & $>1000$ & 0 & $>1000$ & ridge-top \\
\hline 20 & Hills & 5 & $>1000$ & 0 & $>1000$ & ridge-top \\
\hline 21 & Hills & 30 & $>1000$ & 20 & $>1000$ & ridge-top \\
\hline 22 & Hills & 120 & $>1000$ & 0 & $>1000$ & ridge-top \\
\hline 23 & Hills & 20 & $>1000$ & 0 & $>1000$ & ridge-top \\
\hline 24 & Hills & 60 & $>1000$ & 50 & 500 & slope \\
\hline 25 & Hills & 2 & $>1000$ & 0 & 500 & flats \\
\hline 27 & Hills & 2 & $>1000$ & 0 & 300 & creek-bed \\
\hline 28 & Plains & 150 & $>1000$ & 0 & 300 & flats \\
\hline 29 & Hills & 50 & $>1000$ & 0 & $>1000$ & slope \\
\hline 30 & Hills & 15 & 15 & 15 & $>1000$ & slope \\
\hline 31 & $\ldots \quad$ Hills & 15 & 15 & 15 & $>1000$ & slope \\
\hline 32 & Hills & 5 & 5 & 5 & $>1000$ & slope \\
\hline 33 & Hills & 2 & 2 & 2 & $>1000$ & slope \\
\hline 34 & Riverine & 5 & 5 & 5 & $>1000$ & flats \\
\hline 35 & Hills & 150 & 150 & 150 & 120 & slope \\
\hline 36 & Hills & 25 & 25 & 25 & $>1000$ & slope \\
\hline 37 & Plains & 50 & 50 & 50 & $>1000$ & flats \\
\hline 38 & Plains & 120 & 120 & 120 & $>1000$ & flats \\
\hline 39 & Plains & 160 & 160 & 160 & $>1000$ & flats \\
\hline 40 & Plains & 130 & 130 & 130 & $>1000$ & flats \\
\hline 41 & Hills & 20 & $>1000$ & 0 & $>1000$ & slope \\
\hline 42 & Riverine & 5 & 5 & 0 & $>1000$ & flats \\
\hline 44 & Karst & 200 & $>1000$ & 200 & 0 & flats \\
\hline 45 & Plains & 120 & $>1000$ & 120 & 120 & flats \\
\hline 46 & Riverine & 80 & 80 & 0 & $>1000$ & slope \\
\hline 47 & Riverine & 120 & 120 & 0 & $>1000$ & ridge-top \\
\hline 48 & Riverine & 100 & 100 & 0 & $>1000$ & ridge-top \\
\hline 49 & Riverine & 150 & 150 & 0 & $>1000$ & ridge-top \\
\hline 50 & Riverine & 100 & 100 & 0 & $>1000$ & ridge-top \\
\hline 51 & Riverine & 80 & 80 & 0 & $>1000$ & ridge-top \\
\hline 52 & Riverine & 10 & 10 & 0 & $>1000$ & ridge-top \\
\hline
\end{tabular}


Table 14. Mean numbers of artefacts per site by season, the Plains land unit.

\begin{tabular}{|l|c|}
\hline & $\begin{array}{c}\text { Mean Number of Lithics } \\
\text { Per Site }\end{array}$ \\
\hline $\begin{array}{l}\text { early \&/or late wet } \\
\text { season }\end{array}$ & 14.9 \\
\hline dry season & 3.4 \\
\hline
\end{tabular}

Table 15. Mean numbers of artefacts per site by season, the Hills land unit.

\begin{tabular}{|l|c|}
\hline & $\begin{array}{c}\text { Mean Number of Lithics } \\
\text { Per Site }\end{array}$ \\
\hline $\begin{array}{l}\text { early \&/or late wet } \\
\text { season }\end{array}$ & 2.7 \\
\hline wet season & 4.2 \\
\hline $\begin{array}{l}\text { indeterminate wet or } \\
\text { dry season }\end{array}$ & 5.2 \\
\hline
\end{tabular}

Table 16. Mean numbers of artefacts per site by season, the Riverine Zone land unit.

\begin{tabular}{|l|c|}
\hline & $\begin{array}{c}\text { Mean Number of Lithics } \\
\text { Per Site }\end{array}$ \\
\hline dry season & $>100$ \\
\hline $\begin{array}{l}\text { indeterminate wet or } \\
\text { dry season }\end{array}$ & 48 \\
\hline
\end{tabular}

\section{Discussion}

Site patterning in the Chillagoe region indicates that the largest open sites of the late Holocene occur near water courses, and that they were probably used and re-used during the dry season. All other sites are small and appear to have been ephemeral, with stone artefact production not being particularly intensive at those sites. The Plains appear to have been used for camping purposes throughout the year, with the possible exception of the peak of the wet season, when widespread rainfall created boggy conditions. The Hills were used throughout the wet season, their importance for site location decreasing during the dry season. The Riverine Zone was particularly important during the dry season, especially where permanent water sources occurred.

Interestingly, 12 of the $21(57 \%)$ purported early-tolate wet season sites are located within $1 \mathrm{~km}$ of the Limestone Zone; none of the eight dry season sites is thus located. The implication is that the Limestone Zone may have been an important site locational determinant during the wet season. This pattern is consistent with the ability of the Limestone Zone to offer shelter from rainfall, as well as shade in the heat of the wet season (when high temperatures average $35^{\circ} \mathrm{C}$, some $10^{\circ} \mathrm{C}$ above the dry season mean). It is also consistent with the seasonal pattern of resource availability in the various land units (see below).
The above spatial and seasonal site distributions indicate that while each land unit may have been used to some degree throughout the year, the Riverine Zone may have acted as a residential focus during the dry season, and the Limestone Zone as a similar focus during the wet. Most sites were small and of short duration, although some larger, seasonal aggregations took place near waterholes during the dry season and/or during the first or last stages of the wet. During the dry season populations lived mainly in small, ephemeral groups on the Plains and at times in more permanent camps on the Riverine Zone. The latter may have been re-used annually. There is little evidence for camping in the Hills during the dry season. This patterning is consistent with the availability of plant food resources in the various land units, with tubers (especially Boehavia diffusa, Cayratia trifolia, Ipomea eriocarpa and Tribulus sp.) being abundant in the Plains and fish being concentrated in waterholes of the Riverine Zone during the dry season.

The peak of the wet season, on the other hand, was probably not a time when large groups of people came together in central places. The wet season witnessed a focus of camps away from the Riverine Zone to the Limestone Zone (where some 22 species of edible fruits became available at the beginning of the wet), although again most, if not all, land units were used to some extent. The size and/or duration of camps on the Plains may have increased at the beginning and the end of the wet season, but not during periods of high rainfall. This increase coincided in time with a change in the availability of local plant resources, from tubers to fruits (in particular Grewia retusifolia and Santalum lanceolatum in the Plains, with a coincident increased availability of fruits in the Limestone Zone), although this is not to suggest that the changing availability of plant resources was the principle cause for changing settlement patterns. Again, most camps were small and ephemeral, although it is possible that rockshelters and the entrances of caves may have been used more intensively at this time.

\section{Conclusion}

The above model of settlement patterning in the Chillagoe region during relatively recent prehistoric times is necessarily coarse-grained, given the nature of the evidence at hand. Nevertheless, it has been possible to generate a number of hypothesis which now need testing. A number of lines of enquiry could be used with this aim in mind, including: 1. historical and ethnographic evidence; 2. seasonality indicators from faunal and vegetation remains in archaeological sites (e.g. brush turkey egg shells); and 3. the presence of seasonallyspecific plant residues on stone artefact edges (e.g. starch grains of seasonal tubers). Once the above model has been tested and refined, the dynamics of settlementsubsistence systems through time in Chillagoe prehistory will be able to be investigated.

At this stage, an interesting contrast appears to have existed between the 'recent' settlement systems noted above and those of the last glacial maximum (c.22,000BP$17,000 \mathrm{BP}$ ), with the latter involving an apparent 
narrowing of resource catchment areas, accompanied by a greater reliance and increased permanency of settlements near permanent waterholes (cf. David 1994, Lamb in press). It is only with further research in both open and sheltered sites, in all land units, that these patterns can be further explored.

\section{Acknowledgments}

This work was undertaken as part of my M.A. research at the Australian National University (A.N.U.). I would like to thank: Ann Nicholson and Christoph Meier for helping with the surveys; the Department of Archaeology and Anthropology, A.N.U., under whose auspices this research was undertaken; the Australian Museum for a Grant-inAid; the Archaeology Branch, Department of Community Services for a M.A. scholarship; Kari Barz, Sue Feary, Mike Hermes, David Horton, Robert Paton, Wilfred Shawcross and Liz Williams, who gave useful advice when this paper was first written in draft form in 1984; and Mike Rowland for encouraging this work. Thanks also to Ian Lilley and Jay Hall for useful comments on an earlier draft.

\section{References Cited}

BIRKETT, C. 1983 Corridor of karst and creek: a site catchment analysis $\backslash$ of Walkunder Arch Cave, near Chillagoe, north Queensland. B.A. (Honours) thesis, James Cook University of North Queensland, Townsville.

CAMPBELL, J.B. 1982 New radiocarbon results for north Queensland prehistory. Australian Archaeology 14:62-66.

CAMPBELL, J.B. 1984 Extending the archaeological frontier: a review of work on the prehistory of north Queensland. Queensland Archaeological Research 1:173-184.
DAVID, B. 1983 To pick a bone. B.A. (Honours) thesis, The Australian National University, Canberra.

DAVID, B. 1984 Interim report on field-work in the Rookwood-Mungana region, northern Queensland. Report to the Archaeology Branch, Department of Community Services (now Cultural Heritage Section, Department of Environment and Heritage), Brisbane.

DAVID, B. 1987 Chillagoe - from archaeology to prehistory. M.A. thesis, The Australian National University, Canberra.

DAVID, B. 1991 Fern Cave, rock art and social formations: rock art regionalisation and demographic models in southeastern Cape York Peninsula. Archaeology in Oceania 26 (2):41-57.

DAVID, B. 1994 A space-time odyssey: rock art and regionalisation in north Queensland prehistory. $\mathrm{PhD}$ thesis, The University of Queensland, St. Lucia.

DE KEYSER, F. \& WOLFF, K.W. 1964 The geology and mineral resources of the Chillagoe area, Queensland. Bulletin 70, Bureau of Mineral Resources, Canberra.

HAYDEN, B. 1979 Palaeolithic reflections. Australian Institute of Aboriginal Studies, Canberra.

LAMB, L. 1993 Fern Cave: a technological investigation of increased stone artefact deposition rates. B.A. (Honours) thesis, The University of Queensland, St. Lucia.

LAMB, L. in press Investigating stone artefact technology, site use, and intensity of occupation at Fern Cave. Australian Archaeology.

MARDAGA-CAMPBELL, M. 1986 Prehistoric livingfloors and evidence for them in north Queensland rockshelters. Australian Archaeology 23:42-61.

WRIGHT, R.V.S. 1971 Prehistory in the Cape York Peninsula. In D.J. Mulvaney and J. Golson (eds.), Aboriginal Man and Environment in Australia, pp. 133-140. Australian National University Press, Canberra. 